\title{
CD45 expression discriminates waves of embryonic megakaryocytes in the mouse
}

\section{Isabel Cortegano, ${ }^{1}$ Natalia Serrano, ${ }^{2}$ Carolina Ruiz, ${ }^{1}$ Mercedes Rodríguez, ${ }^{1}$ Carmen Prado, ${ }^{1}$ Mario Alía, ${ }^{1}$ Andrés Hidalgo, ${ }^{3}$ Eva Cano, ${ }^{4}$ Belén de Andrés ${ }^{1}$ and María-Luisa Gaspar ${ }^{1}$}

${ }^{1}$ Department of Immunology, Centro Nacional de Microbiología, Instituto de Salud Carlos III (ISCIII), Majadahonda; ${ }^{2}$ Centro de Biología Molecular Severo Ochoa, Consejo Superior de Investigaciones Científicas (CBMSO-CSIC), Madrid; ${ }^{3}$ Area of Cell and Developmental Biology, Centro Nacional de Investigaciones Cardiovasculares, Madrid and ${ }^{4}$ Neuroinflamation Unit, Chronic Diseases Research Program, Instituto de Salud Carlos III (ISCIII), Majadahonda, Spain

\section{ABSTRACT}

E mbryonic megakaryopoiesis starts in the yolk sac on gestational day 7.5 as part of the primitive wave of hematopoiesis, and it continues in the fetal liver when this organ is colonized by hematopoietic progenitors between day 9.5 and 10.5, as the definitive hematopoiesis wave. We characterized the precise phenotype of embryo megakaryocytes in the liver at gestational day 11.5, identifying them as $\mathrm{CD} 41^{++} \mathrm{CD} 45^{-}$ $\mathrm{CD}^{++} \mathrm{CD} 61^{+} \mathrm{MPL}{ }^{+} \mathrm{CD} 42 \mathrm{c}^{+}$tetraploid cells that express megakaryocyte-specific transcripts and display differential traits when compared to those present in the yolk sac at the same age. In contrast to megakaryocytes from adult bone marrow, embryo megakaryocytes are CD45 until day 13.5 of gestation, as are both the megakaryocyte progenitors and megakaryocyte/erythroid-committed progenitors. At gestational day 11.5, liver and yolk sac also contain $\mathrm{CD} 41^{+} \mathrm{CD} 45^{+}$and $\mathrm{CD} 41^{+} \mathrm{CD} 45$ cells. These populations, and that of $\mathrm{CD} 41^{++} \mathrm{CD} 45 \mathrm{CD} 42 \mathrm{c}^{+}$cells, isolated from liver, differentiate in culture into $\mathrm{CD} 41^{++} \mathrm{CD} 45 \mathrm{CD} 42 \mathrm{c}^{+}$proplatelet-bearing megakaryocytes. Also present at this time are $\mathrm{CD} 411^{-} \mathrm{CD} 45^{++} \mathrm{CD} 11 \mathrm{~b}^{+}$cells, which produce low numbers of $\mathrm{CD} 41^{++} \mathrm{CD} 45 \mathrm{CD}^{-} 2 \mathrm{c}^{+}$megakaryocytes in vitro, as do fetal liver cells expressing the macrophage-specific Csf receptor-1 (Csf1r/CD115) from MaFIA transgenic mice, which give rise poorly to $\mathrm{CD} 41^{++} \mathrm{CD} 45 \mathrm{CD} 42 \mathrm{c}^{+}$embryo megakaryocytes both in vivo and in vitro. In contrast, around $30 \%$ of adult megakaryocytes $\left(\mathrm{CD} 41^{++} \mathrm{CD} 45^{++} \mathrm{CD}^{++} \mathrm{CD} 42 \mathrm{c}^{+}\right)$from C57BL/6 and MaFIA mice express CD115. We propose that differential pathways operating in the mouse embryo liver at gestational day 11.5 beget $\mathrm{CD} 41^{++} \mathrm{CD} 45 \mathrm{CD} 42 \mathrm{c}^{+}$ embryo megakaryocytes that can be produced from $\mathrm{CD} 41^{+} \mathrm{CD} 45$ or from $\mathrm{CD} 41^{+} \mathrm{CD} 45^{+}$cells, at difference from those from bone marrow.

\section{Introduction}

Megakaryocytes are the hematopoietic cells responsible for the production of platelets. In adults, these cells are generated in the bone marrow (BM) from hematopoietic stem cells (HSC) via a common megakaryocyte and erythroid progenitor (MEP) that expresses the receptor for SCF (c-Kit) and is negative for lineage-specific antigens (Lin), for the stem cell antigen-1 (Sca1), and for the fms-related tyrosine kinase 3 receptor, Flt3/CD135 (Flt3:LSK cells). ${ }^{1}$ Nevertheless differentiation into all hematopoietic lineages, including the megakaryocyte/erythroid, from $\mathrm{Flt}^{+}$progenitors was also obtained. ${ }^{2}$ The hierarchical model of hematopoiesis defines progressively restricted lineage-committed progenitors. From HSC a pool of multipotent progenitors (MPP) produces common lymphoid progenitors (CLP) and common myeloid progenitors (CMP), these latter giving rise to MEP and granulocyte/macrophage progenitors (GMP) ${ }^{3.4}$ However, several recent reports suggest that megakaryocyte/erythroid-commitment may happen directly from HSC or from MPP, supporting a model of multiple lineage commitments occurring in parallel within the HSC/MPP cell pool..$^{5.8}$ Among CMP, CD41+ cells that express a megakaryocyte-specific signa-
Ferrata Storti Foundation

Haematologica 2019

Volume 104(9):1853-1865

\section{Correspondence:}

ISABEL CORTEGANO

icortegano@isciii.es

MARÍA-LUISA GASPAR

mlgaspar@isciii.es

Received: March 8, 2018.

Accepted: December 14, 2018.

Pre-published: December 20, 2018.

doi:10.3324/haematol.2018.192559

Check the online version for the most updated information on this article, online supplements, and information on authorship \& disclosures: www.haematologica.org/content/104/9/1853

(C)2019 Ferrata Storti Foundation

Material published in Haematologica is covered by copyright. All rights are reserved to the Ferrata Storti Foundation. Use of published material is allowed under the following terms and conditions:

https://creativecommons.org/licenses/by-nc/4.0/legalcode. Copies of published material are allowed for personal or internal use. Sharing published material for non-commercial purposes is subject to the following conditions:

https://creativecommons.org/licenses/by-nc/4.0/legalcode, sect. 3. Reproducing and sharing published material for commercial purposes is not allowed without permission in writing from the publisher. 
ture, platelet factor 4 (PF4), CD9, von Willebrand factor (VWF), are separated from erythroid progenitors, and closer to other myeloid progenitors expressing Flt3 and the macrophage colony-stimulating factor-1 receptor (Csf1r/CD115). ${ }^{7}$ Clonal unilineage megakaryocyte progenitors $(\mathrm{MKP})$ were defined as burst-forming unit megakaryocytes (BFU-MK) and as colony-forming unit megakaryocytes (MK-CFU), and were Linc-Kit ${ }^{+}$Sca1 FcyRII/III ${ }^{10} \mathrm{CD} 127-$ Thy $1.1^{-} \mathrm{CD}^{++} \mathrm{CD}^{+} 1^{+}$cells expressing the thrombopoietin receptor (myeloproliferative leukemia virus, MPL). ${ }^{1,9}$ Other studies revealed distinct lineage potentials among erythromyeloid progenitors, ${ }^{10}$ defining megakaryocyte/erythroid-committed progenitors (PreMegE) as Lin ${ }^{-}{ }^{-}{ }^{-} \mathrm{Kit}^{+} \mathrm{Fc} \gamma \mathrm{R} \cdot \mathrm{CD} 105 \mathrm{CD}^{-}$150 $^{+} \mathrm{CD} 41^{-}$and MKP, exclusively associated with megakaryocyte generation, as Lin ${ }^{-} \mathrm{Ca}{ }^{-} \mathrm{C}-\mathrm{Kit}^{++} \mathrm{CD} 150^{+} \mathrm{CD} 41^{+}$.

Embryo hematopoiesis proceeds in two phases, primitive and definitive, which are conserved among different species, including mice and humans. ${ }^{11,12}$ In the mouse, a primitive wave of erythromyeloid cells forms in the yolk sac (YS) at E7.5.13,14 At E8.5 erythromyeloid progenitors are generated in the YS and the intraembryonic paraaortic splanchnopleura/aorta-gonads-mesonephros region (P$\mathrm{Sp} / \mathrm{AGM}$ ), the latter also containing progenitors with lymphoid activity. ${ }^{15-17}$ Definitive HSC that are the source of all adult hematopoietic cell lineages are present in the P$\mathrm{Sp} / \mathrm{AGM}$ at E10.5..$^{18}$ The emergence of these definitive HSC in the embryo is dependent on the expression of the transcription factor RUNX1, ${ }^{19}$ which is required for progression of CD $41^{+}$embryonic precursors into HSC. ${ }^{20}$ The fetal liver (FL) represents the major hematopoietic organ during gestation, receiving extrinsic HSC and MPP from the YS, P$\mathrm{Sp} / \mathrm{AGM}$ and the placenta at E10.5. MEP involved in primitive and definitive megakaryopoiesis appear in the YS at E7.25 and at E9.5, respectively. ${ }^{21,22}$ RUNX1-independent diploid platelet-forming cells have been identified in the YS at E8.5/10.5. ${ }^{23}$ Moreover, CD42 $\mathrm{c}^{+}$megakaryocytes can be identified in the YS, in circulation and in the FL from E9.5 onwards, and large reticulated immature platelets circulate at E10.5..$^{21,24}$

Embryo-derived megakaryocytes differ from those from the adult BM, as illustrated by the in vitro effects of thrombopoietin, ${ }^{25}$ cell-intrinsic differences in vivo after transplantation $^{26}$ and the smaller size of those from YS. ${ }^{22}$ In the FL from E10.5-E11.5 mice, megakaryocytes progressively increase in size and ploidy. ${ }^{27}$ However, despite several reports on BMderived megakaryopoiesis published recently, the intermediate cells that appear during this process early in life, and the changes in surface phenotype, have yet to be fully defined.

We found previously that at E10.5/E11.5, FL megakaryocytes are c-Kit ${ }^{\mathrm{D}} \mathrm{CD} 49 \mathrm{f}^{++} \mathrm{CD} 41^{++} \mathrm{CD}{ }^{++} \mathrm{CD} 42 \mathrm{c}^{+} \mathrm{VWF}^{+}$and they rapidly produce, independently of thrombopoietin stimulation, proplatelet-bearing megakaryocytes ( $\mathrm{P}-\mathrm{MK})$ in vitro. ${ }^{28}$ Strikingly, these FL megakaryocytes were $\mathrm{CD} 41^{++} \mathrm{CD} 45$, as were the diploid platelet-forming cells found in the YS. ${ }^{23}$ Here we show that, unlike those from BM, FL megakaryocytes remain CD45 until E13.5, as do the PreMegE and MKP. However, both $\mathrm{CD} 41^{+} \mathrm{CD} 45^{+}$and $\mathrm{CD} 41^{+} \mathrm{CD} 45$ cells are present in the $\mathrm{FL}$, these populations bearing $\mathrm{MK}-\mathrm{CFU}$, megakaryocyte gene expression, and containing LinSca1 ${ }^{-}$- $\mathrm{Kit}^{++} \mathrm{CD} 150^{+} \mathrm{CD} 41^{+} \mathrm{MKP}$. These cells develop into $\mathrm{CD} 41^{++} \mathrm{CD} 45 \mathrm{CD} 42 \mathrm{c}^{++} \mathrm{P}-\mathrm{MK}$ in vitro. The E11.5

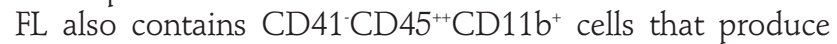
$\mathrm{CD} 41^{+} \mathrm{CD} 45^{+}$cells in vitro, although they do not develop into P-MK. Accordingly, CD45 ${ }^{++} \mathrm{EGFP}^{+}$cells from E11.5 FL ex vivo preparations from MaFIA transgenic mice, which trace cells expressing Csf1r/CD115, ${ }^{29}$ give origin poorly to $\mathrm{CD} 1^{++}$cells both in vivo and in vitro. Interestingly, a high proportion of adult $\mathrm{BM} \mathrm{CD} 41^{++} \mathrm{CD} 45^{++} \mathrm{CD} 9^{++} \mathrm{CD} 42 \mathrm{c}^{++}$ megakaryocytes from C57BL/6 mice express CD115 and are $\mathrm{EGFP}^{+}$in MaFIA mice. Our results identify different pathways of megakaryopoiesis in the mouse embryo FL and in adult BM, driven by distinct MKP expressing or not CD45.

\section{Methods}

\section{Mice and embryo microsurgery and cell suspensions}

$\mathrm{BALB} / \mathrm{c}$, C57BL/6 and C57BL/6-Tg(Csf1r-EGFPNGFR/FKBP1A/TNFRSF6) 2Bck/J MaFIA ${ }^{29}$ mice were maintained at the animal facilities of the Instituto de Salud Carlos III. All animal studies were approved by the Animal Health Ethics Authority from the Autonomous Government of Madrid (PROEX 080/15). Embryo microsurgery and cell suspensions were obtained as described previously ${ }^{28}$ and in the Online Supplementary Methods.

\section{Flow cytometry and cell purification}

Cells were stained as reported elsewhere, ${ }^{28}$ with the fluorochrome-labeled antibodies described in the Online Supplementary Methods and Online Supplementary Tables S1 and S2.

\section{Quantitative real-time polymerase chain reaction analysis}

RNA was extracted, oligo(dT)-primed cDNA samples were prepared and quantitative real-time polymerase chain reaction (RTqPCR) amplifications were performed with the primers and protocols described, ${ }^{30,31}$ as indicated in the Online Supplementary Methods and Online Supplementary Table S3.

\section{Colony-forming cell assays and cell cultures}

Clonal semisolid cultures and cultures of purified cell populations were performed as indicated in the Online Supplementary Methods.

\section{Immunofluorescence}

Immunostaining was performed on cryosections from YS and embryos as indicated in the Online Supplementary Methods. The preparations were analyzed by confocal microscopy (Leica DMRD) and the images were processed with ImageJ software.

\section{Statistical analysis}

GraphPad Prism 4.0 software was used to calculate the means and standard error of the mean (SEM). Comparisons were performed with unpaired and paired Student t tests, with the $\chi^{2}$ test or the Kruskal-Wallis test, to obtain the $P$ values. Data are expressed as mean \pm SEM. A $P$-value less than 0.05 was defined as statistically significant; statistical significance is shown as ${ }^{*} P<0.05$, ${ }^{* *} P<0.01$ and ${ }^{* * *} P<0.001$.

\section{Results}

Megakaryocyte lineage cells are present in hematopoietic organs and blood vessels during post-gastrulation embryo development

Co-expression of the CD41/aIIa integrin (GPIIb) and CD $42 \mathrm{c} / \mathrm{GPIb}-\beta$ chains was used to trace megakaryocytes and platelets by flow cytometry. $\mathrm{CD}^{2} 1^{++} \mathrm{CD} 42 \mathrm{c}^{+}$ 
megakaryocytes were detected from E9.5 in the YS, and in the circulating peripheral blood mononuclear cells and the P-Sp/AGM from this moment on (Figure 1A). Similarly, $\mathrm{CD} 41^{++} \mathrm{CD} 42 \mathrm{c}^{+}$cells were found from E10.5 in the FL, although the mean fluorescence intensity (MFI) of CD41 in $\mathrm{CD} 41^{++} \mathrm{CD} 42 \mathrm{c}^{+}$megakaryocytes was weaker than that at other locations, as particularly evident in E11.5 samples (Figure 1B). CD $41^{++} \mathrm{CD} 42 \mathrm{c}^{+}$megakaryocytes were more abundant in the YS than in the P-Sp/AGM and FL at E10.5, and their numbers increased along gestation (Figure $1 \mathrm{C}$ ). Cells in the window corresponding to platelets (low forward scatter/side scatter on a log scale) were also detected in the YS and FL from E8.5 and E10.5, respectively, and they were in the circulation from E9.5 (Figure 1D) as described previously. ${ }^{23}$ Consistent with previous reports, ${ }^{21}$ the earliest platelets were large and although their size diminished in the YS and FL as gestation progressed, those circulating remain large until E13.5 (Figure 1E).

Megakaryocytes in the E9.5-E11.5 mouse embryo accumulate in the fetal liver

To trace the anatomic distribution of $\mathrm{CD} 41^{++}$ megakaryocytes at E11.5 in the YS and embryo, immunofluorescence analyses were performed. YS preparations contained clusters of small CD41++ cells that may correspond to aggregated platelets, as well as individual megakaryocytes (Figure 2A). In the embryo proper, CD $41^{++}$megakaryocytes were enriched in the FL. From E10.5 to E15.5, FL CD41 $1^{++}$megakaryocytes increased in volume and enhanced the complexity of the so-called membrane demarcation system (DMS, involved in proplatelet formation), indicating maturation to megakaryo-
A

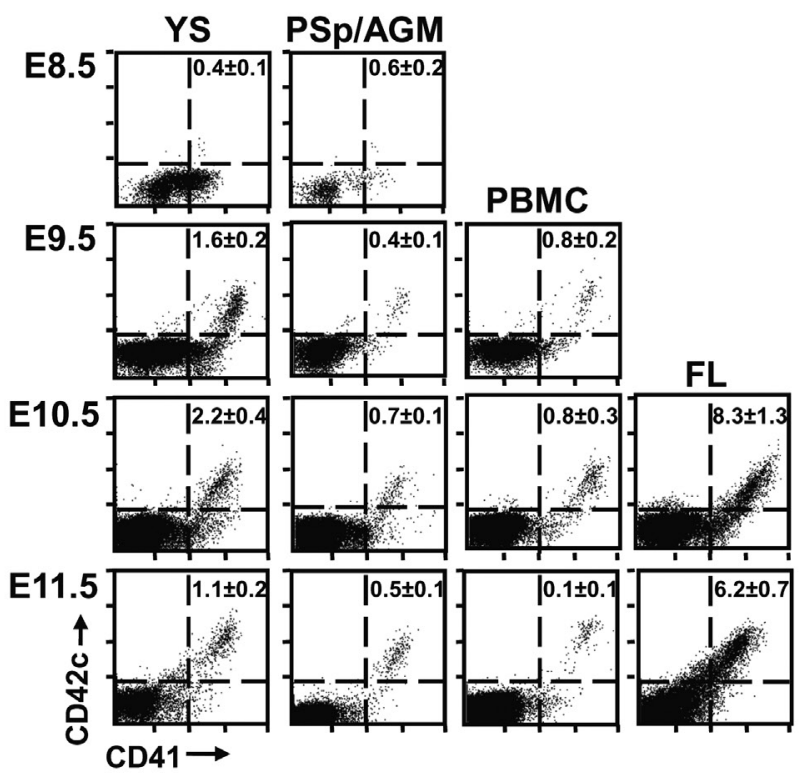

D
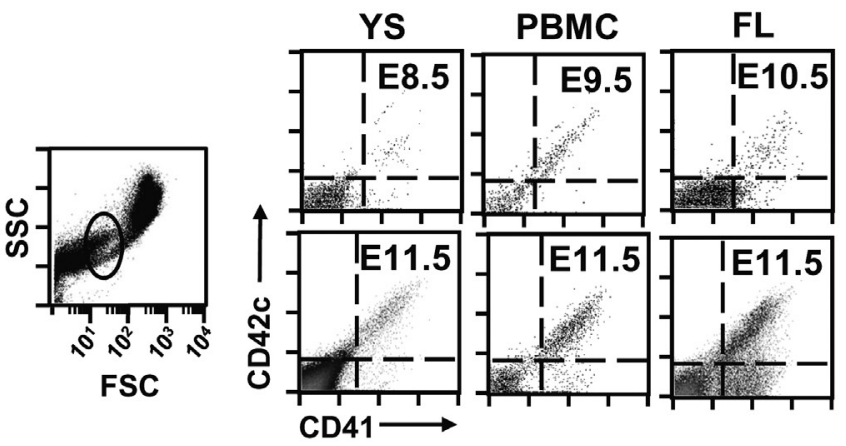

B

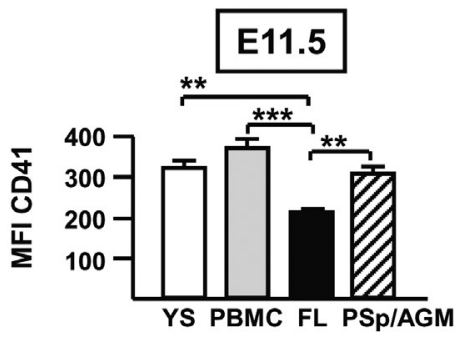

C

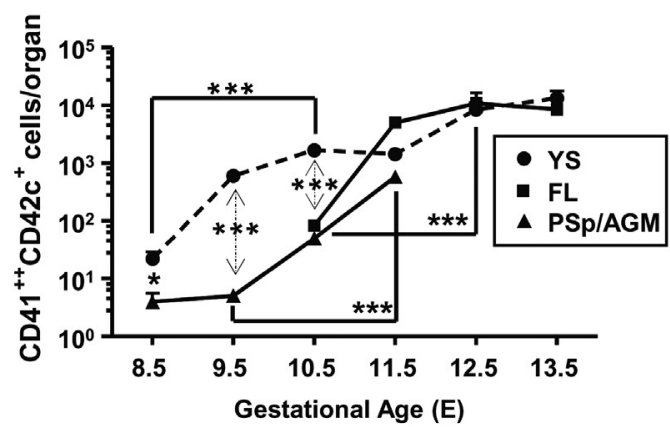

$\mathrm{E}$

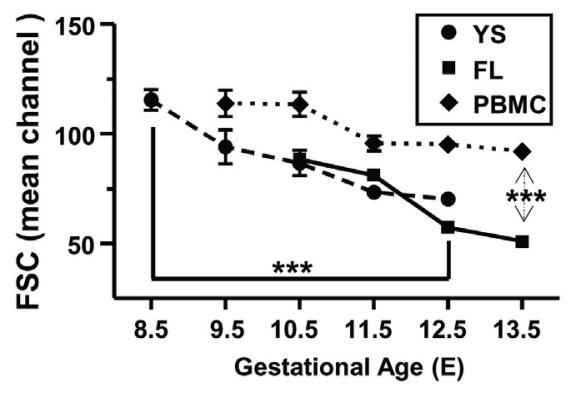

Figure 1. Megakaryocyte lineage cells are present from E9.5 in the mouse embryo. Cell suspensions from hematopoietic locations in the embryo were prepared and stained with anti-CD41-PE and anti-CD42c-FITC for cytometry. (A) Representative dot-plots of the staining of cell suspensions from the yolk sac (YS), paraaortic splanchnopleura/aorta-gonads-mesonephros region (P-Sp/AGM), peripheral blood mononuclear cells (PBMC) and fetal liver (FL) at the gestational ages indicated (from E8.5 to E11.5). The quadrants define positive cells (determined by using fluorescence-minus-one control isotypes) and the numbers inside the plots are the frequencies of $C D 41^{++} \mathrm{CD} 42 \mathrm{c}^{+}$cells [mean \pm standard error of mean (SEM) $n=5, n=6, n=7$, and $n=16$ for E8.5, E9.5, E10.5 and E11.5, respectively]. (B) The bar graphs show the mean fluorescence intensity (MFI) of the CD41 fluorescence among $\mathrm{CD} 41^{++} \mathrm{CD} 42 \mathrm{C}^{+}$cells from the locations indicated at E11.5. (C) Absolute numbers of $\mathrm{CD} 41^{++} \mathrm{CD} 42 \mathrm{C}^{+}$cells in the YS, P-Sp/AGM and FL from E8.5-E13.5, as derived from the frequencies displayed in the histograms in panel (A) and the total number of cells recovered per organ in each preparation. (D) Representative dot-plots of the CD41 and CD42c staining in cells gated in the low side scatter (SSC)/forward scatter (FSC) window shown in the left dot-plot with the scale FSC as logarithmic, corresponding to platelets. (E) The graph represents the size (determined by the mean FSC channel) of the cells identified in the low SSC/FSC platelet window, in the YS, PBMC and FL from E8.5 to E13.5. The data in the graphs in (B, C and E) are the means \pm SEM [numbers as in panel $(A)$, and $n=8$ and 17 for E12.5 and E13.5, respectively]. Fluorescence scales are logarithmic. The group comparisons were performed with a two-tailed Student $t$-test. $* * P<0.01$ and $* * * P<0.001$. 
cyte stages with increased ploidy ${ }^{32}$ (Figure 2B-E). In fact, most CD $41^{++} \mathrm{CD} 42 \mathrm{c}^{+}$megakaryocytes from E11.5 FL were tetraploid (4N or more) (Figure $2 \mathrm{~F}$ ). By contrast, YS CD41 ${ }^{++}$ megakaryocytes were smaller and mostly diploid, as described for the diploid platelet-forming cells. ${ }^{23}$ At E10.5, FL megakaryocytes displayed a less complex membrane demarcation system than the concurrent YS diploid platelet-forming cells, although the latter did not reach greater membrane demarcation system complexity at E11.5, as did those from FL (Figure 2D).

As we found previously, ${ }^{28}$ E11.5 $\mathrm{CD}^{2} 1^{++} \mathrm{VWF}^{+}$ megakaryocytes were consistently CD45, and only weak CD45 signals were detected in CD41 ${ }^{\text {lo }}$ cells (Figure $3 \mathrm{~A}$ ). Flow cytometry analyses of YS and FL cell suspensions from E10.5-E15.5 embryos showed that CD $41^{++} \mathrm{CD} 42 \mathrm{c}^{+}$ megakaryocytes were mainly CD45 in the YS and FL until E13.5 (population \#1 in Figure 3B-C), whereas CD45+ cells were detected among the $\mathrm{CD} 41^{+} \mathrm{CD} 42 \mathrm{c}^{-}$cells (population \#2) in these same preparations. Also, most embryo megakaryocytes from E11.5 placenta were CD45 (Figure 3C). From E13.5 onwards, $\mathrm{CD} 41^{++} \mathrm{CD} 42 \mathrm{c}^{+}$megakaryo- cytes displayed low levels of CD45, which increased at E15.5, and megakaryocytes from adult BM were CD45 (Figure 3C). Accordingly, CD45 was not detected by RTqPCR in $\mathrm{CD}_{4} 1^{++} \mathrm{CD} 42 \mathrm{c}^{+}$samples from the YS and FL at E11.5, while they expressed Runx1 (Figure 3D).

The fact that $\mathrm{CD} 41^{++} \mathrm{CD} 42 \mathrm{c}^{+}$megakaryocytes were mostly CD45 in the YS and FL until E13.5 suggested that the initial FL megakaryocytes may be derived by the homing of CD45 megakaryocytes from the YS. The expression of selected markers by the $\mathrm{CD} 41^{++} \mathrm{CD} 45$ cells present in the YS and FL between E10.5 to E11.5 (c-Kit and CD42c) (Table 1) indicated a maturation of these cells in the YS (the brightness of c-Kit dropped and the expression of CD42c increased) that was not so evident in the FL during the same period, and consequently at E11.5 CD $41{ }^{++} \mathrm{CD} 45$ cells in the FL showed weaker CD41 fluorescence (Figure 1B), and stronger c-Kit expression (Table 1) than those in the YS at E11.5.

Therefore, our data show that at E11.5 YS and FL megakaryocytes differ in their cell volume and ploidy. Those from YS are diploid platelet-forming cells while
A
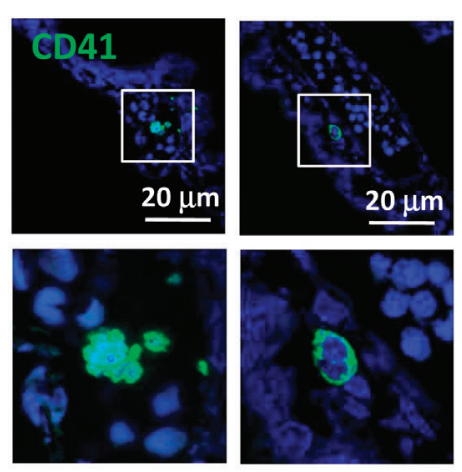

B
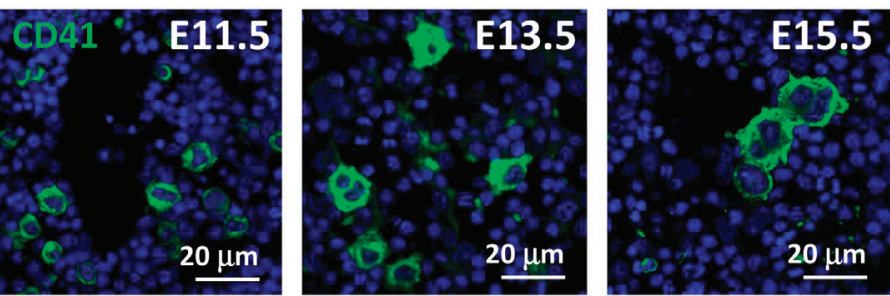

C
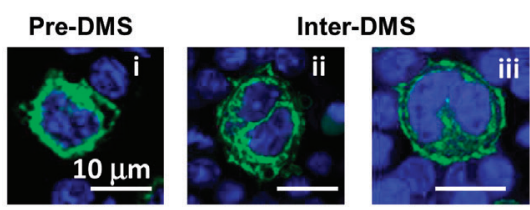

Late-DMS

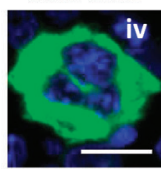

E

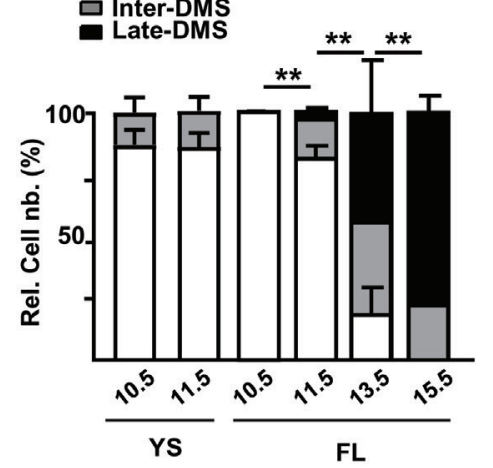

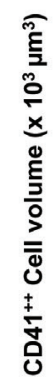

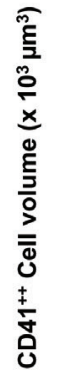

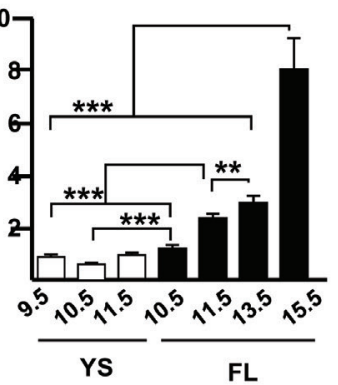

$\mathbf{F}$

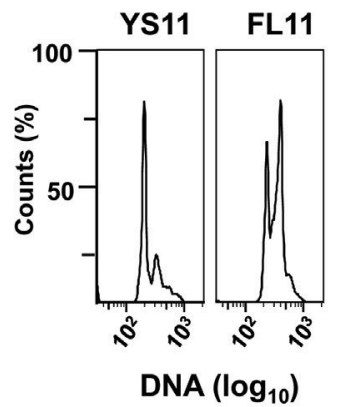

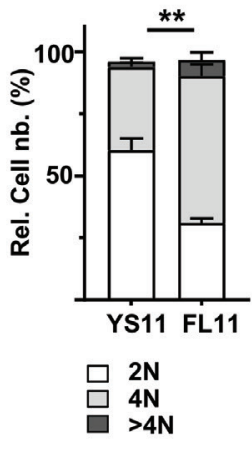

Figure 2. Topographical and morphological characteristics of embryo megakaryocytes. Immunofluorescence analyses on E11.5 yolk sac (YS) and embryo tissue slices $(10 \mu \mathrm{m})$ stained with anti-CD41-FITC (green), and counterstained with DAPI. Representative photomicrographs are shown. The scale bar indicates the magnification of the photomicrographs. (A) The upper photomicrographs show two views of YS samples. The white boxes define the areas magnified in the bottom photomicrographs. (B) The photomicrographs show fetal liver (FL) samples at the gestational ages indicated. (C) Higher magnification of representative megakaryocytes displaying the increased complexity of the membrane demarcation system (DMS) used to define the Pre-DMS (i), Inter-DMS (ii and iii) and Late-DMS (iv) stages. (D) The bar graph displays the relative number (percentage) of YS and FL megakaryocytes presenting the DMS stages identified in the CD41 ${ }^{++}$megakaryocytes at the gestational ages indicated. (E) The graph displays the cell volume of CD41++ cells. The volume $\left(\pi \mathrm{D}^{3} \times 1.33\right)$ was calculated after measuring the cell diameter " $\mathrm{D}$ ". One hundred cells were counted in 20 different photomicrographs for each time point. Data in panels (D) and (E) are the mean \pm standard error of mean (SEM) for YS preparations at E9.5 $(n=6)$, E10.5 $(n=9)$ and E11.5 $(n=9)$, and for FL samples at E10.5 $(n=3)$, E11.5 $(n=16)$, E13.5 $(n=9)$ and E15.5 $(n=8)$. $(F)$ Left, representative histograms showing the DAPI staining in nuclei of electronically gated CD41 ${ }^{++} \mathrm{CD} 42 \mathrm{C}^{+}$embryo-derived megakaryocytes (EMK) present in cell suspensions from YS and $\mathrm{FL}$ at E11.5; right, quantification of cells with $2 \mathrm{~N}, 4 \mathrm{~N}$ or $>4 \mathrm{~N}$ ploidy among $\mathrm{CD} 41^{++} \mathrm{CD} 42 \mathrm{C}^{+} \mathrm{EMK}$. The mean $\pm \mathrm{SEM}$ are shown $(\mathrm{n}=3$ ). Comparisons were performed in contingency tables with $\chi^{2}$ and Fisher exact tests. $* * P<0.01$ and $* * * P<0.001$. 
those in FL are bigger and mostly tetraploid cells, and express higher levels of Runx1, even though they bear less CD41 and CD42c intensity than those in the YS. From E11.5 to E15.5, FL megakaryocytes increase in size, as well as membrane complexity and become CD $45^{+}$.

\section{Weak CD45 expression in megakaryocyte progenitors} in the E11.5 embryo

In the adult BM, all nucleated stages of megakaryocyte differentiation are $\mathrm{CD}_{4} 5^{+}{ }^{33}$ Since most megakaryocytes were CD45 at E11.5, we wondered whether megakaryo- cyte lineage-committed progenitors were also CD45 at these embryonic stages. We therefore determined the number of cells expressing CD45, and the levels of CD45, among LSK, PreMegE, MKP, CMP, GMP and CLP cells (their phenotypes are defined in Online Supplementary Table S1) in E11.5 FL cell suspensions, comparing these with cells from the liver and BM of newborn mice (postnatal day 3, PD3) and from those in the adult BM. The level of CD45 expression was weaker in E11.5 samples than in those from adult mice. Remarkably, both the frequency of cells expressing CD45 and the levels of CD45
A
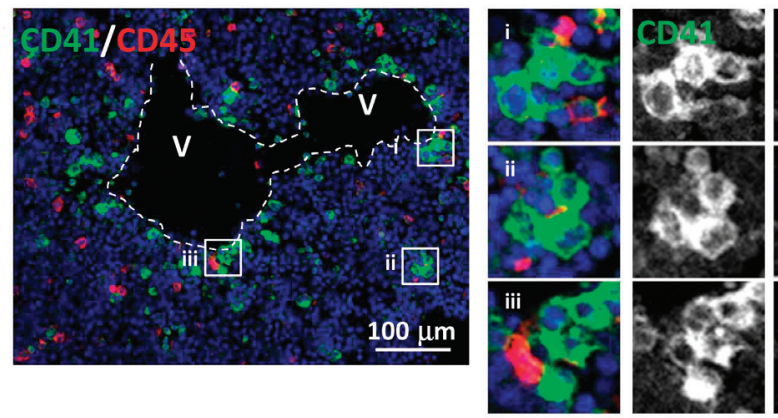

C

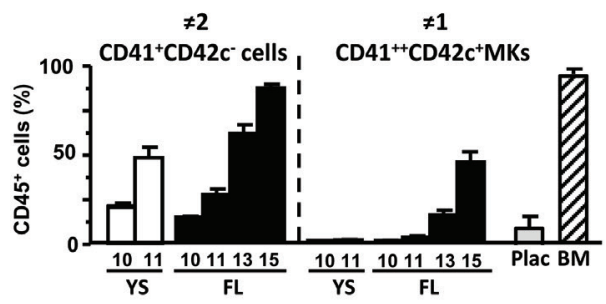

E

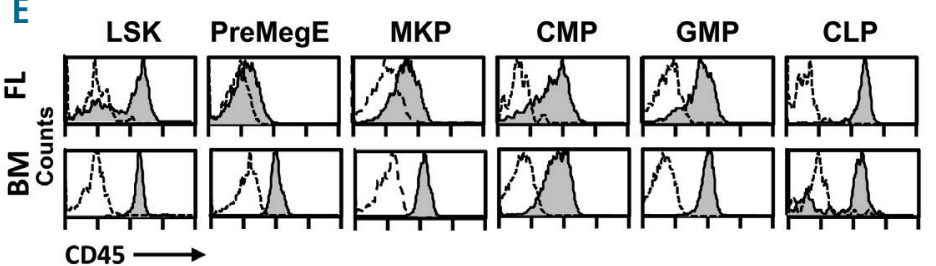

D

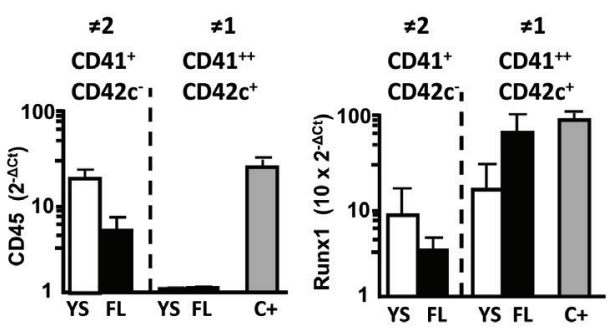

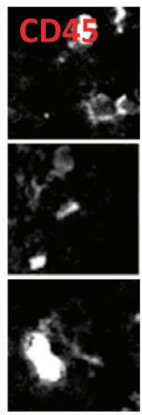

B
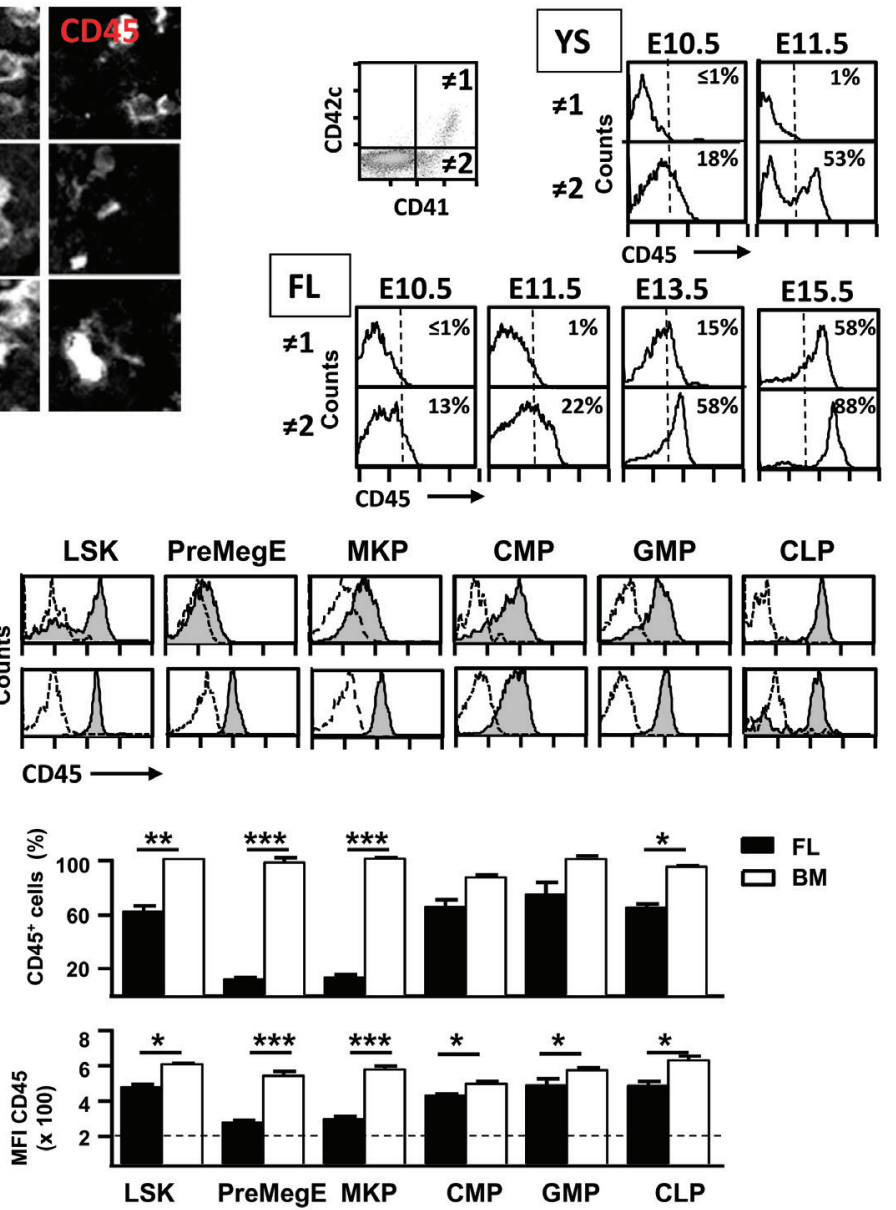

Figure 3. Megakaryocytes and megakaryocyte-lineage committed progenitors are CD45 in the yolk sac and embryo at E10.5-E13.5. (A) Left photomicrograph: the fetal liver (FL) in an embryo preparation stained with anti-CD41 (green) and anti-CD45 (red). The boundaries of the vessel (V) are indicated by the dotted line. Right photomicrographs: higher magnification of cells indicated by the white boxes showing overlaid signals and separated in channels. Green CD41 ${ }^{++}$cells negative for the red CD45 stain are shown. (B) Yolk sac (YS) and FL cell suspensions from E10.5, E11.5, E13.5 and E15.5 embryos were stained with anti-CD41-PE, anti-CD42CFITC and anti-CD45-PE-Cy7. The upper-left dot-plot displays a representative CD41/CD42c staining showing the CD41 ${ }^{++} \mathrm{CD} 42 \mathrm{C}^{+}$megakaryocytes and CD41+CD42Ccell populations (labeled as 1 and 2, respectively) analyzed for expression of CD45 in the histograms. The vertical lines in the histograms indicate the fluorescenceminus-one (FMO) isotype control limit. Numbers inside the histograms are the percentages of positive cells. (C) Bar graphs showing the quantification (relative number) of CD45 cells among the CD41 $C D 42 c$ cells and CD41 ${ }^{++} C D 42 c^{+}$megakaryocytes. The mean \pm standard error of mean $(S E M)$ for $E 10.5$ ( $\left.n=9\right)$, E11.5 ( $n=9$ ), E13.5 $(n=9)$, E15.5 $(n=8)$, placenta $(n=4)$ and adult bone marrow (BM) $(n=4)$ is shown. (D) CD45 and Runx1 expression analyzed by real-time quantitative polymerase chain reaction on samples of purified $\mathrm{CD} 41^{+} \mathrm{CD} 42 \mathrm{C}$ and $\mathrm{CD} 41^{++} \mathrm{CD} 42 \mathrm{C}^{+}$cells from the $\mathrm{E} 11.5 \mathrm{YS}$ and $\mathrm{FL}$. The results were calculated relative to the expression of the HPRT housekeeping gene using the $2^{-\Delta c t}$ method. The data are the mean \pm SEM $(n=4)$. Results for total FL at E11.5 are shown as $C+$. (E) After tracing and electronically excluding Lin ${ }^{+}$cells with biotin-labeled antibodies against Ter119, B220, CD19, CD11b and anti-CD90.2 revealed with the fluorochrome-labeled streptavidin indicated below, progenitor populations in E11.5 FL and adult BM cell suspensions were identified by multicolor flow cytometry by using combinations of antibodies, as follows: (i) anti-Sca1-PE-Cy7, anti-c-Kit-APC, anti-Flt3-PE, and streptavidin-FITC to identify LSK (Linc-Kit ${ }^{++}$Sca1 ${ }^{+}$) cells and common lymphoid progenitors (CLP: Linc-Kit'Sca1+); and (ii) antic-KitAPC, anti-CD34-BV421, anti-FcyRII/III-FITC, anti-CD150-PerCp-Cy5.5, and anti-CD41-PE, with anti-Sca1-PE-Cy7 and streptavidin-PE-Cy7, to identify granulocyte/macrophage progenitors (GMP: Linc-Kit ${ }^{++}$Sca1 CD34 ${ }^{+}$Fc $\gamma \mathrm{RII} / \mathrm{III}^{++}$), common myeloid progenitors $\left(\mathrm{CMP}\right.$ : Lin C-Kit ${ }^{++}$Sca1 $\mathrm{CD} 34^{++} \mathrm{Fc} \gamma \mathrm{RII} / \mathrm{III}$ ), megakaryocyte/erythroid-committed progenitors (PreMegE: LinSca1 ${ }^{-}$Kit $^{+} \mathrm{CD} 150^{++} \mathrm{CD} 41$ ) and megakaryocyte progenitors (MKP: LinSca1 ${ }^{-}$ $\left.\mathrm{Kit}^{+} \mathrm{CD} 15 \mathrm{O}^{++} \mathrm{CD} 41^{+}\right)$. CD45 expression was monitored with anti-CD45-APC-Cy7. The histograms show the expression of CD45 by progenitor cells in the E11.5 FL and adult BM (filled gray histograms). The FMO isotype signal is shown overlaid (dotted line). The data shown are from one representative experiment. Fluorescence scales are logarithmic. (F) The quantification (frequency) of CD45+ cells and their mean fluorescence intensity (MFI) in the CD45 channel are shown in the bar graphs. The horizontal dotted line represents the isotype background limit. The data in the graphs are the means \pm SEM ( $n=5$ ), comparing the groups with the twotailed Student $t$-test. $* P<0.05, * * P<0.01$ and $* * * P<0.001$. 
Table 1. Expression of surface receptors in $\mathrm{CD} 45 \mathrm{CD} 41^{++}$megakaryocytes from the yolk sac and fetal liver.

\begin{tabular}{|c|c|c|c|c|c|c|c|}
\hline & E10.5 YS & E11.5 YS & E10.5 FL & E11.5 FL & $\begin{array}{c}\text { P value } \\
\text { E11.5 YS/FL }\end{array}$ & $\begin{array}{c}P \text { value } \\
\text { YS E10.5/E11.5 }\end{array}$ & $\begin{array}{c}P \text { value } \\
\text { FL E10.5/E11.5 }\end{array}$ \\
\hline \multicolumn{8}{|l|}{ MFI } \\
\hline c-Kit-APC & $\begin{array}{c}246 \pm 35 \\
(3)\end{array}$ & $\begin{array}{c}188 \pm 10 \\
(12)\end{array}$ & $\begin{array}{c}281 \pm 10 \\
(3)\end{array}$ & $\begin{array}{l}273 \pm 14 \\
(12)\end{array}$ & $P<0.001$ & $P<0.05$ & \\
\hline CD42c-FITC & $\begin{array}{l}402 \pm 11 \\
(8)\end{array}$ & $\begin{array}{c}474 \pm 10 \\
(10)\end{array}$ & $\begin{array}{c}326 \pm 9 \\
(7)\end{array}$ & $\begin{array}{l}383 \pm 12 \\
(8)\end{array}$ & $P<0.001$ & $P<0.001$ & $P<0.01$ \\
\hline \multicolumn{8}{|l|}{ Frequency } \\
\hline c-Kit-APC & $\begin{array}{c}60 \pm 11 \\
(4)\end{array}$ & $\begin{array}{r}63 \pm 2 \\
(6)\end{array}$ & $\begin{array}{r}75 \pm 7 \\
(5)\end{array}$ & $\begin{array}{r}77 \pm 4 \\
(6)\end{array}$ & $P<0.01$ & & \\
\hline CD42c-FITC & $\begin{array}{r}90 \pm 1 \\
(8)\end{array}$ & $\begin{array}{r}95 \pm 1 \\
(8)\end{array}$ & $\begin{array}{r}82 \pm 2 \\
(8)\end{array}$ & $\begin{array}{r}90 \pm 1 \\
(8)\end{array}$ & $P<0.01$ & $P<0.01$ & $P<0.01$ \\
\hline
\end{tabular}

The mean fluorescence intensity (MFI) of electronically gated CD45CD41+ cells was determined.Values are the mean \pm standard error of mean and (number). The statistical significances were calculated using unpaired and paired $t$ tests (the latter when values were obtained from the same pools of embryos). E: embryonic day; YS: yolk sac; FL: fetal liver.

were much lower in LSK cells, PreMegE and MKP at E11.5 than in adult BM (Figure 3E-F). In neonates, CD45 expression increased in progenitors from liver, although remaining lower in PreMeg and MKP than in those from neonatal and adult BM (Online Supplementary Figure S1). Hence, our data show that at E11.5, not only megakaryocytes, but also LSK, PreMegE and MKP display less CD45 than at $\mathrm{PD} 3$ and in adult mice.

\section{CD45 ${ }^{+}$and CD45 megakaryocyte lineages are present at E11.5}

Adult BM megakaryocytes are Lin $\mathrm{CD} 41^{++} \mathrm{CD} 45^{+}$acetylcholinesterase $(\mathrm{AChE})^{+}$, while immature megakaryocytes are Lin $\mathrm{CD}^{2} 5^{+} \mathrm{CD} 41^{+} \mathrm{AChE} \cdot{ }^{34}$ To identify whether $\mathrm{CD} 41^{+} \mathrm{CD} 45^{+}$immature megakaryocytes equivalent to those from BM were present in the E11.5 embryo, we analyzed CD41/CD45 expression in cell preparations from the YS and FL. At E11.5 there are CD45 cell populations that are negative or positive for CD41 (R1/CD $41{ }^{-C D} 45^{++}$and $\mathrm{R} 2 / \mathrm{CD} 41^{+} \mathrm{CD} 45^{+}$, respectively). Among CD45 cells there are cells expressing low or high levels of CD41 (R3/CD41 ${ }^{+} \mathrm{CD} 45$ and $\mathrm{R} 4 / \mathrm{CD} 41^{++} \mathrm{CD} 45$, respectively), or negative for it (DN cells). R2/CD $41^{+} \mathrm{CD} 45^{+}$cells were highly prominent in the YS at E9.5 and E10.5, and R1/CD41 $\mathrm{CD}^{2+} 5^{++}$and $\mathrm{R} 3 / \mathrm{CD} 41^{+} \mathrm{CD} 45$ cells, the first apparent from E10.5, and increasing as development proceeded (Figure 4A-B). Signals for AChE were obtained only for the purified $\mathrm{R} 2 / \mathrm{CD} 41^{+} \mathrm{CD} 45^{+}$and $\mathrm{R} 4 / \mathrm{CD} 41^{++} \mathrm{CD} 45$ cell subsets (Figure $4 \mathrm{C}$ ). The R2/CD $41^{+} \mathrm{CD} 45^{+}$cells in $\mathrm{FL}$ can be further subdivided based on higher or lower CD45 level (Online Supplementary Figure S2C; R2a and R2b, respectively), with few $\mathrm{CD}_{4} 5^{+}$cells displaying high levels of CD41 (Online Supplementary Figure S2C,D; R2c). Expression of the megakaryocyte-related cell surface markers CD42c, MPL, $\mathrm{CD} 9$ and $\mathrm{CD} 61$ was found in $\mathrm{R} 4 / \mathrm{CD} 41^{++} \mathrm{CD} 45$ and R3/CD41 ${ }^{+} \mathrm{CD} 45$ cells in YS and FL at E10.5/E11.5, and also in the $\mathrm{R} 2 \mathrm{c} / \mathrm{CD} 41^{++} \mathrm{CD} 45^{+}$cell subset in FL (Figure $4 \mathrm{D}$ and Online Supplementary Figures S2 and S3). Since the number of $\mathrm{R} 2 \mathrm{c} / \mathrm{CD} 41^{++} \mathrm{CD} 45^{+}$cells was low (Online Supplementary Figure S2D), there were fewer $\mathrm{CD} 41^{++} \mathrm{CD} 45^{+} \mathrm{CD} 42 \mathrm{c}^{+}$ megakaryocytes than $\mathrm{CD} 41^{++} \mathrm{CD} 45 \mathrm{CD} 42 \mathrm{c}^{+}$megakaryocytes at E10.5-E11.5, in agreement with the results displayed in Figure 3B,C. Megakaryocyte-lineage-specific transcripts NF-E2, PF4, VWF and Fli1 were expressed by $\mathrm{R} 4 / \mathrm{CD} 41^{++} \mathrm{CD} 45$ cells, which displayed myeloid-specific transcripts (PU1 and myeloperoxidase) very weakly (Figure 4E, and data not shown). From now on we will refer to the $\mathrm{CD} 41^{++} \mathrm{CD} 45 \mathrm{CD} 42 \mathrm{c}^{+}$megakaryocytes present in the R4 region in FL samples as embryo-derived megakaryocytes (EMK), and to the $\mathrm{CD} 41^{++} \mathrm{CD} 45^{+} \mathrm{CD} 42 \mathrm{c}^{+}$cells as adult-type megakaryocytes (AMK). When analyzed for the presence of earlier hematopoietic progenitors by flow cytometry (Figure 4F), R4/CD41++CD45 cells comprise only few MKP besides the EMK. Accordingly, when the differentiation potential of purified $\mathrm{R} 4 / \mathrm{CD} 41^{++} \mathrm{CD} 45$ cells from E11.5 FL cell suspensions was analyzed on clonal MegaCult and MethoCult assays (Figure 4G), they only produced megakaryocyte lineage colonies (MK-CFU), and myeloid lineage colonies (M-CFU) in which P-MK were detected as individual cells, like $\mathrm{CD} 45^{+} \mathrm{CD} 41^{++} \mathrm{CD} 42 \mathrm{c}^{+}$ megakaryocytes from adult BM (Online Supplementary Figure S4C).

The $\mathrm{R} 2 / \mathrm{CD} 41^{+} \mathrm{CD} 45^{+}$and $\mathrm{R} 3 / \mathrm{CD} 41^{+} \mathrm{CD} 45$ cell subsets also expressed VWF, yet they had a mixture of other progenitors, containing Linc-Kit ${ }^{++}$subpopulations with the phenotype of GMP, MKP, low numbers of CMP, and in the case of $\mathrm{R} 3 / \mathrm{CD} 41^{+} \mathrm{CD} 45$ cells, also PreMegE, as did $\mathrm{CD} 41^{+} \mathrm{CD} 45^{+}$cells from adult BM (Online Supplementary Figure $S 4 A, B)$. Consequently, $\mathrm{R} 2 / \mathrm{CD} 41^{+} \mathrm{CD} 45^{+}$cells from FL and BM produced both MK-CFU and M-CFU, and the $\mathrm{R} 3 / \mathrm{CD} 41^{+} \mathrm{CD} 45$ cell population from FL produced E/MCFU (Figure 4G and Online Supplementary Figure S4C). On the other hand, R1/CD41 $\mathrm{CD} 45^{++}$cells were mainly $\mathrm{Lin}^{+} \mathrm{CD} 11 \mathrm{~b}^{+}$, but also contained CLP, CMP and GMP, and produced M-CFU and E/M-CFU. Likewise they accumulated PU1 and myeloperoxidase myeloid-specific transcripts, as did the R2/CD $41^{+} \mathrm{CD} 45^{+}$cells (Figure 4E-G). By contrast, purified DN/CD41 $\mathrm{CD} 45$ cells mostly produced E-CFU progenitors and no MK-CFU (Figure 4G).

In summary, the expression of AChE and other surface and molecular markers, as well as clonal megakaryocyte and hematopoietic lineage differentiation assays indicated that $\mathrm{R} 4 / \mathrm{CD} 41^{++} \mathrm{CD} 45 \mathrm{CD} 42 \mathrm{c}^{+}$cells are EMK with low proliferative activity and prone to develop proplatelets in vitro, as expected for mature megakaryocytes. The $\mathrm{R} 2 / \mathrm{CD} 41^{+} \mathrm{CD} 45^{+}$and $\mathrm{R} 3 / \mathrm{CD} 41^{+} \mathrm{CD} 45$ cells contain oligoclonal progenitors including MKP, which could represent, respectively, $\mathrm{CD}_{4} 5^{+}$adult-like intermediate stages (iAMK) and CD $45^{\circ}$ embryo intermediate stages (iEMK) in the differentiation of the megakaryocyte lineage. 
A

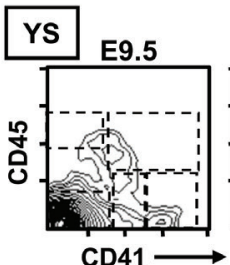

B

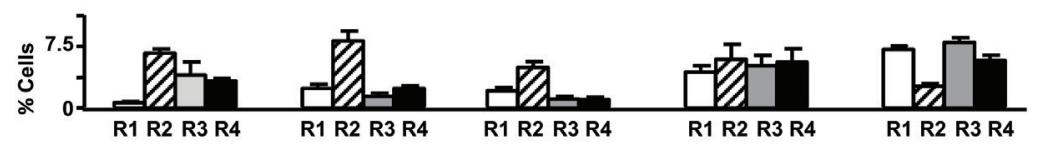

D
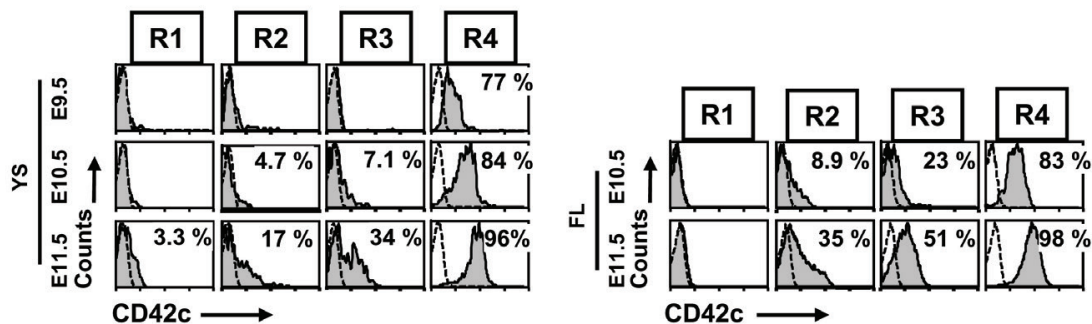

E
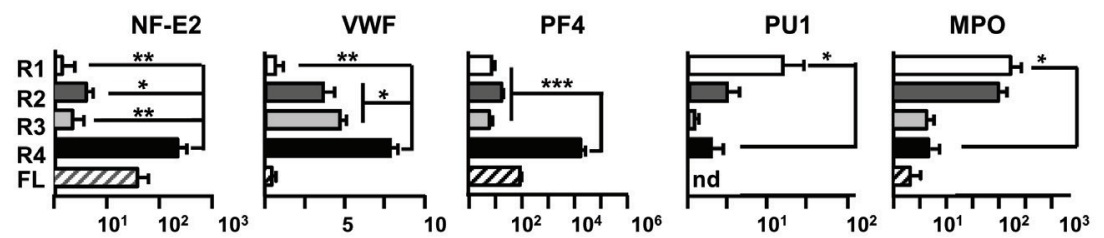

C

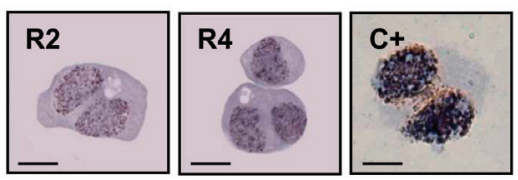

$F$
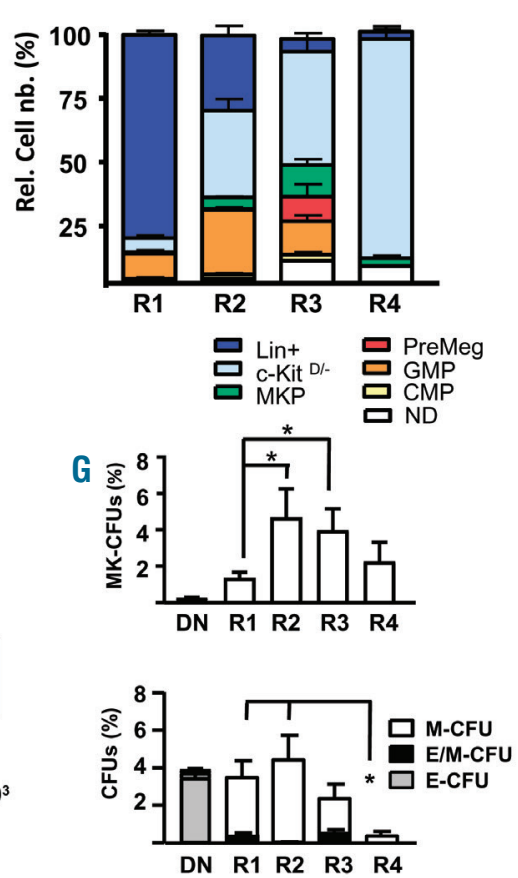

Figure 4. $\mathrm{CD}^{+} 5^{+}$and $\mathrm{CD} 45$ megakaryocyte subsets are present at E11.5 in the yolk sac and fetal liver. Flow cytometry studies were performed on preparations from E11.5 fetal liver (FL) cell suspensions using Ter119-PerCP.Cy5.5, CD41-PE, CD45-PE-Cy7 and CD42c-FITC antibodies to analyze CD41/CD45/CD42C expression after electronically excluding Ter119+ cells. Fluorescence scales are logarithmic. (A) Representative contour plots of the yolk sac (YS) and FL cell preparations at the indicated gestational ages. The boxes inside the dot plots identify four cell subsets expressing CD45 and/or CD41, which are labeled (R1-R4 and DN) as indicated in the YS E11.5 dot-plot. (B) The bar graphs represent the frequency of each population (R1-R4) as the means \pm standard error of mean (SEM) (E9.5, $n=6$; E10.5, $\mathrm{n}=8$; E11.5, $n=9$ ). (C) Acetylcholinesterase (AChE) expression (brown dots) was determined in the purified cell populations indicated from the E11.5 FL. Representative photomicrographs from one of three experiments of hematoxylin-eosin counterstained cells are shown. $\mathrm{C}^{+}$cells are purified $\mathrm{CD} 9^{++} \mathrm{CD} 41^{++} \mathrm{CD} 42 \mathrm{C}^{+}$cells from E17.5 FL cell suspensions. Bar, 10 um. (D) Representative histograms showing the expression of CD42c (gray histograms) in the populations defined in (A), in which each point was analyzed at least three times. The fluorescence-minus-one (FMO) isotype signal is shown overlaid (dotted line). The numbers inside the plots represent the frequency of CD42c cells in this experiment, representative of three performed with similar results. (E) Expression of NF-E2, VWF, PF4, PU1 and MPO transcripts in cDNA samples from the E11.5 FL CD45/CD41 cell populations purified by flow cytometry as indicated in panel (A). The values for each transcript were calculated relative to the HPRT gene using the $2^{-4 c t}$ method. The bars represent the means \pm SEM. R1, $n=5 ; R 2, n=4 ; R 3, n=9 ; R 4, n=6$. (F) Relative numbers of progenitor cells present in the indicated CD45/CD41 cell subsets. The data are means \pm SEM. $(n=3)$. Progenitor cell populations were identified as in Figure $3 E-F$ and Online Supplementary Table S1. (G) Clonal differentiation assays. Purified cells from the E11.5 FL populations indicated were seeded in semisolid MegaCult medium (upper graph) and in semisolid MethoCult medium (bottom graph). The colonies grown in MethoCult (erythroid and myeloid colony-forming units: E-CFU and M-CFU) and MegaCult (megakaryocyte colony-forming units: MK-CFU) were counted at 3, 7 and 10 days, respectively. The data are the means \pm SEM ( $n=4$ ). Comparisons among groups were performed with the two-tailed Student $t$-test. $* P<0.05, * * P<0.01$ and $* * * P<0.001$.

In vitro megakaryocyte differentiation stages from $\mathrm{CD}^{4} 5^{+}$and $\mathrm{CD} 45^{\circ}$ megakaryocyte lineages in the fetal liver at E11.5

In order to reproduce the steps of megakaryocyte differentiation in vitro, we used short-term liquid cultures (STLC) to trace the differentiation of cells from purified R1-R4 E11.5 FL cell suspensions defined in Figure 4A, and from purified adult $\mathrm{BM} C \mathrm{CD} 41^{+} \mathrm{CD} 45^{+} \mathrm{CD} 42 \mathrm{c}$ and $\mathrm{CD} 41^{++} \mathrm{CD} 45^{+} \mathrm{CD} 42 \mathrm{c}^{+}$cells. These STLC have the advantage of rapidly producing sufficient cells for phenotypic and genetic analyses while allowing morphological changes to be observed. After $24 \mathrm{~h}$ in STLC, EMK (R4) from E11.5 FL produced adherent cells and other elongated and mobile cells which, after $48 \mathrm{~h}$, emitted proplatelets and were $\mathrm{CD}^{2} 1^{++} \mathrm{CD} 45 \mathrm{CD} 42 \mathrm{c}^{++} \mathrm{P}-\mathrm{MK}$ (Figures $5 \mathrm{~A}-\mathrm{D}$ ).
STLC of R2/CD $41^{+} \mathrm{CD} 45^{+}$cells also contained CD $41^{++} \mathrm{CD} 42 \mathrm{c}^{+}$megakaryocytes that were either CD $45^{+}$ or $\mathrm{CD} 45$, and very few $\mathrm{CD} 41^{+} \mathrm{CD} 45^{+}$cells $(3.6 \% \pm 1.5 \%$, $\mathrm{n}=4$ ). Similar results were obtained in STLC with $\mathrm{R} 3 / \mathrm{CD} 41^{+} \mathrm{CD} 45^{-}$progenitors, although the $\mathrm{CD} 41^{++} \mathrm{CD} 42 \mathrm{C}^{+}$ cells that developed there were mostly CD 45 (Figure $5 \mathrm{~B}$ ). DNA content analysis of the $\mathrm{CD} 41^{++} \mathrm{CD} 42 \mathrm{c}^{++}$megakaryocytes growing in the STLC from FL R2-R4 cell subsets showed that they accumulated in the $8 \mathrm{~N}$ stage although the megakaryocytes generated in $\mathrm{R} 4 / \mathrm{CD} 41^{++} \mathrm{CD} 45$ cell STLC reached higher ploidy (Figure 5C).

Consistent with the myelo/monocyte traits expressed by R1/CD $41 \mathrm{CD}^{-\mathrm{C} 5^{++}}$cells, these cells generated CD 41 CD $45^{++} \mathrm{CD} 11 \mathrm{~b}^{++}$cells in STLC, and also CD $41^{++} \mathrm{CD} 45^{+1}$ $\mathrm{CD} 42 \mathrm{c}^{+} \mathrm{CD} 11 \mathrm{~b}$ cells (Figure $5 \mathrm{~B}$ and Online Supplementary 
Figure S5A). Accordingly, after STLC there was a bias towards myeloperoxidase expression in cultures from R1/CD 41 CD $45^{++}$cells and towards PF4 in those from $\mathrm{R} 2 / \mathrm{CD} 41^{+} \mathrm{CD} 45^{+}$cells, R3/CD $41^{+} \mathrm{CD} 45$ cells and $\mathrm{R} 4 / \mathrm{CD} 41^{++} \mathrm{CD} 45^{-} \mathrm{EMK}$ (Figure 5E). The $\mathrm{CD} 41^{++} \mathrm{CD} 45^{+} \mathrm{CD} 42 \mathrm{c}^{+}$megakaryocytes generated in R1/CD41 CD45 ${ }^{++}$STLC were not elongated nor did they present a P-MK morphology (Figure 5D). Therefore, during the differentiation to $\mathrm{CD} 41^{++} \mathrm{CD} 45^{-}$megakaryocytes from CD $41 \mathrm{CD}^{-} 5^{++}$and $\mathrm{CD} 41^{+} \mathrm{CD} 45^{+}$cells, a reduction of CD45 levels occurred in conjunction with an increase of CD42c (Figure 5F). Although we found a reduction in the CD45 transcript levels from $\mathrm{CD} 41^{+} \mathrm{CD} 45^{+}$cells in STLC
(Online Supplementary Figure S5B), to rule out that the decrease in expression of membrane-bound CD45 was due to the use of anti-CD45 for the isolation of the cells, we performed STLC with isolated $\mathrm{CD} 31^{++} \mathrm{CD} 42 \mathrm{c}$ cells that contained most $\mathrm{CD} 45^{+/++}$cells. $^{28}$ After $48 \mathrm{~h}$, the $\mathrm{CD} 31^{++} \mathrm{CD} 42 \mathrm{c}^{-}$cells gave rise to $\mathrm{CD} 42 \mathrm{c}^{+}$cells that had reduced their CD45 levels (Online Supplementary Figure S5C). By contrast, STLC from CD $41^{+} \mathrm{CD} 45^{+} \mathrm{CD} 42 \mathrm{c}$ and CD $41^{++} \mathrm{CD} 45^{+} \mathrm{CD} 42 \mathrm{c}^{+}$BM-purified cells (Online Supplementary Figure S4D-E) allowed the growth of large cells and P-MK displaying large proplatelets after $96 \mathrm{~h}$, reaching ploidy stages up to $64 \mathrm{~N}$. The megakaryocytes $\left(\mathrm{CD} 41^{++} \mathrm{CD} 42 \mathrm{c}^{+}\right)$in these cultures were consistently
A

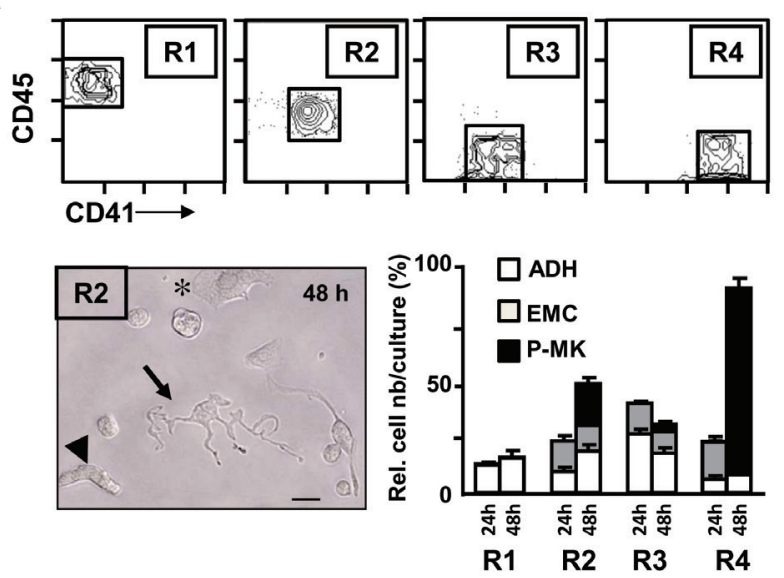

D

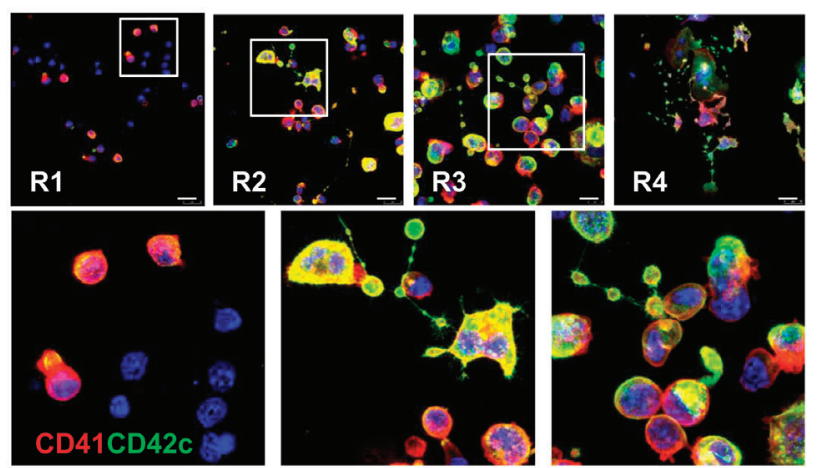

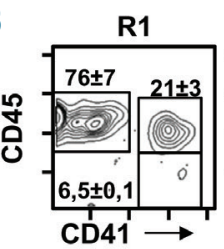
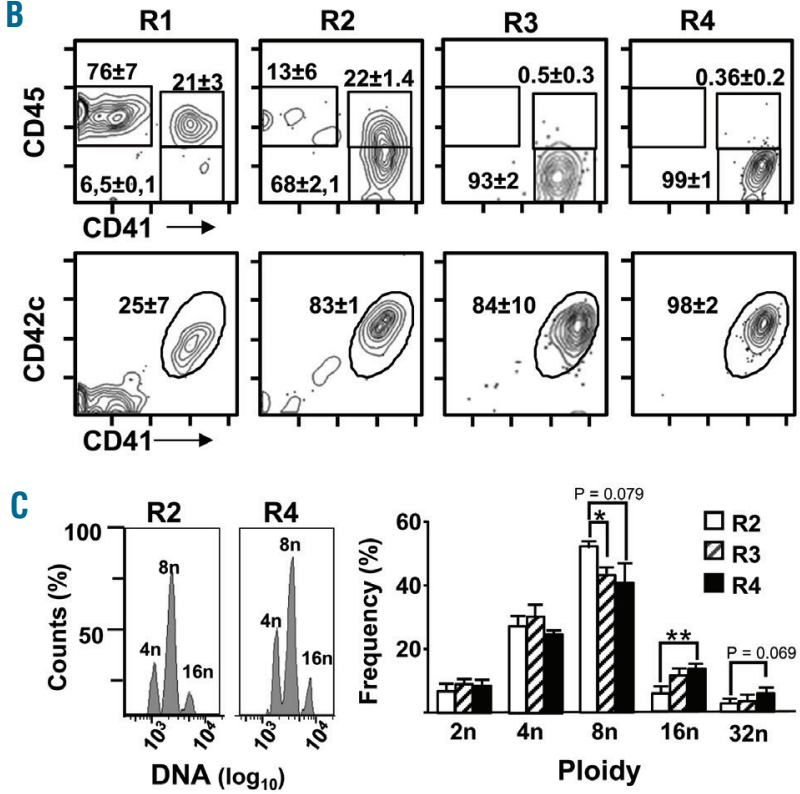

E

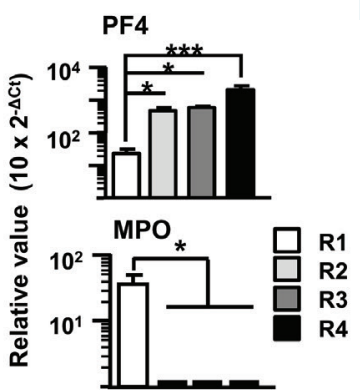

$\mathbf{F}$

MFI CD45 MFI CD42c

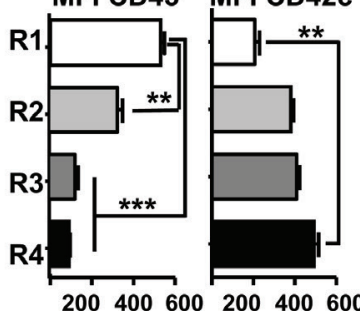

Figure 5. The $\mathrm{CD} 41^{+} \mathrm{CD} 45$ and $\mathrm{CD} 41^{+} \mathrm{CD} 45^{+}$cell populations from $\mathrm{E} 11.5$ fetal liver produce megakaryocytes in vitro. Cells from the $\mathrm{CD} 41 / \mathrm{CD} 45$ populations indicated in Figure 4A were isolated by flow cytometry from E11.5 fetal liver (FL) cell suspensions, and cultured in short-term liquid cultures (STLC) in the presence of $50 \mathrm{ng} / \mathrm{mL}$ recombinant murine thrombopoietin, either in 96-well plates or 8-well culture slides. After 24 and $48 \mathrm{~h}$ the cultures were photographed under light microscopy and the cells were counted in function of their morphology. After $48 \mathrm{~h}$ the cells were recovered and stained in suspension with anti-CD41-PE, anti-CD45PE-Cy7 and anti-CD42C-FITC antibodies for cytometry analyses, or stained in the slides with anti-CD41-biotin/Tyr.Cy3 and anti-CD42c-FITC antibodies. (A) Representative contour plots of cells after the sorting procedure for each population are shown in the upper plots. Below-left, a representative photomicrograph (left panel) of $\mathrm{R} 2 / \mathrm{CD} 41^{+} \mathrm{CD} 45^{+}$cells growing in STLC showing an adherent cell (asterisk, ADH); elongated, mobile cell (arrowhead, EMC); and proplatelet-bearing megakaryocyte (arrow, P-MK). Bar, $10 \mu \mathrm{m}$. The bar chart in the right panel shows the frequency of the cells with these morphologies in cultures from the indicated purified cells. The data are means \pm standard error of mean (SEM) (200 cells counted in 8-9 photographs for each culture, from 4 different experiments counted by 2 independent investigators). (B) Representative contour plots of the indicated cells after $48 \mathrm{~h}$ in culture. The numbers in the plots represent the frequency of the cells in the boxes. Data are means \pm SEM, $n=4$. Fluorescence scales in the plots in panels $(A)$ and $(B)$ are logarithmic. (C) Left, representative histograms showing the DAPI staining in nuclei of electronically gated $\mathrm{CD} 41^{++} \mathrm{CD} 42 \mathrm{C}^{+}$from R2 and R4 cultured cells; right, quantification of cells with $2 \mathrm{~N}-16 \mathrm{~N}$ in $\mathrm{CD} 41^{++} \mathrm{CD} 42 \mathrm{C}^{+}$ megakaryocytes in $48 \mathrm{~h} \mathrm{STLC}$ from R2 (white), R3 (hatched) and R4 (black) cells. The means \pm SEM are shown ( $\mathrm{n}=5$ ). Group comparisons were performed with the two-tailed Student $t$-test. (D) Photomicrographs showing CD41 (red) and CD42c (green) staining in cells grown on culture slides (upper panels): bars represent 25 um (R1, R2 and R4) and 10 um (R3). White squares indicate the areas amplified in the bottom panels. (E) Expression of PF4 and MPO transcripts in cDNA samples from E11.5 FL cell populations after STLC. The values for each transcript were calculated relative to the HPRT gene using the $2^{-4 c t}$ method as in Figure $4 \mathrm{E}$. The bars represent the means \pm SEM. R1, $n=5 ; R 2, n=4 ; R 3, n=9 ; R 4, n=6$. (F) The horizontal bar chart displays the mean fluorescence intensity (MFI) values obtained by cytometry for the CD45 and CD42c fluorescent labeling of cells after $48 \mathrm{~h}$ in cultures from the different subpopulations isolated from the E11.5 FL. The data are means \pm SEM, $n=4$. Group comparisons were performed with the two-tailed Student $t$-test. $* P<0.05, * * P<0.01$ and $* * * P<0.001$. 
$\mathrm{CD} 45^{+}$, indicating that adult megakaryocytes maintain CD45 expression along their differentiation.

In summary, the $\mathrm{IAMK}$ and $\mathrm{iEMK}$ present among $\mathrm{R} 2 / \mathrm{CD} 41^{+} \mathrm{CD} 45^{+}$and $\mathrm{R} 3 / \mathrm{CD} 41^{+} \mathrm{CD} 45^{-}$cells produced $\mathrm{CD} 41^{++} \mathrm{CD} 45 \mathrm{CD} 42 \mathrm{c}^{+} \mathrm{EMK}$ in culture, and in the case of $\mathrm{R} 2 / \mathrm{CD} 41^{+} \mathrm{CD} 45^{+}$cells also $\mathrm{CD} 41^{++} \mathrm{CD} 45^{+} \mathrm{CD} 42 \mathrm{c}^{+} \mathrm{AMK}$, with a characteristic P-MK morphology, while CD $41^{++} \mathrm{CD} 42 \mathrm{c}^{+}$megakaryocytes growing in BM STLC remained $\mathrm{CD}_{4} 5^{+}$. Hence, we conclude that in the $\mathrm{FL}$ at
E11.5, CD45 levels are modulated in the differentiation towards $\mathrm{CD} 41^{++} \mathrm{CD} 42 \mathrm{c}^{+}$megakaryocytes.

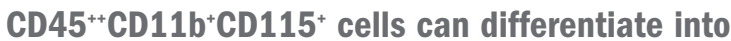
intermediate megakaryocyte stages

As expected from their megakaryocyte potential in CFU assays (Figure 4G), CD41 $\mathrm{CD} 45^{++}$cells also differentiated into $\mathrm{CD} 41^{++} \mathrm{CD} 45^{+} \mathrm{CD} 42 \mathrm{c}^{+}$cells, although at the times of analysis they did not undergo great morphological
A
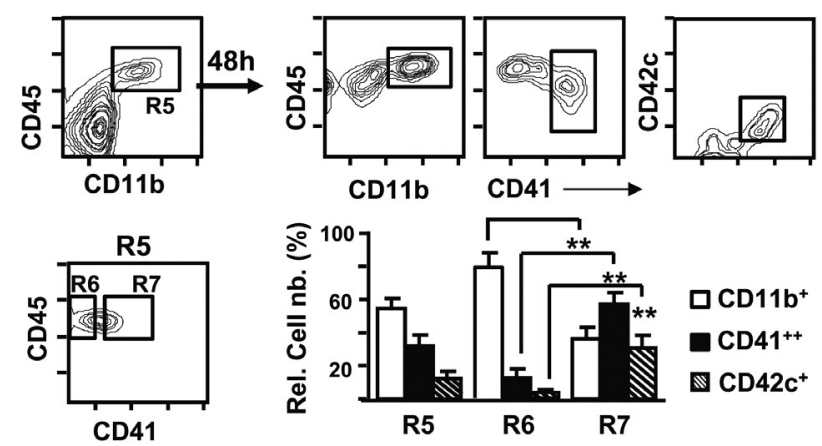

泟

B

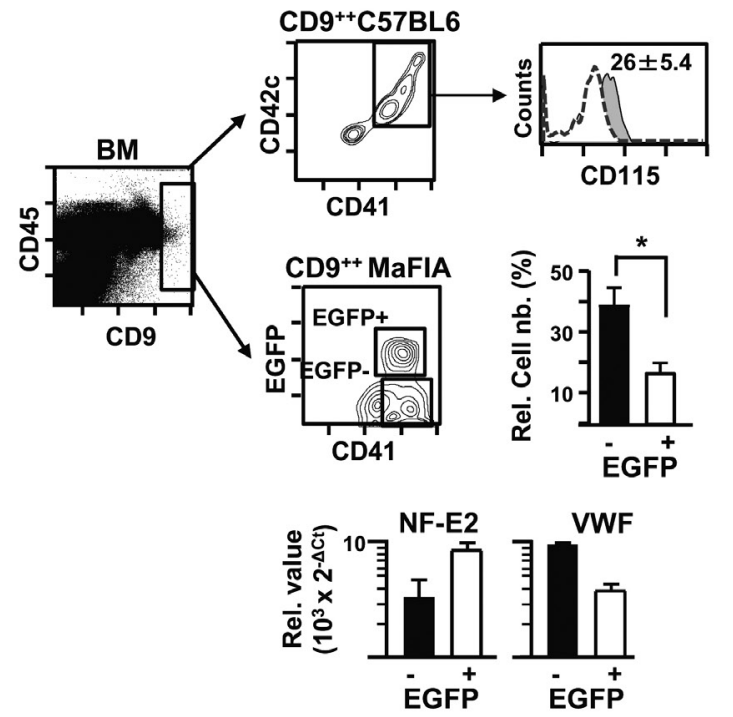

C
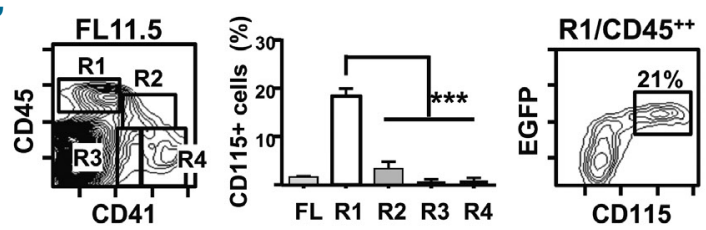

。
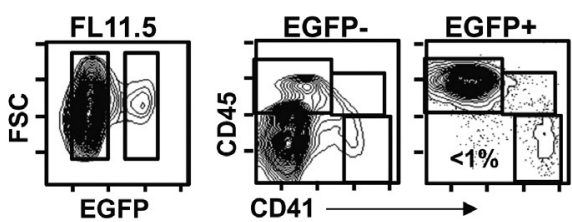

$E$

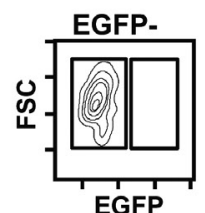

$\downarrow 48 h$
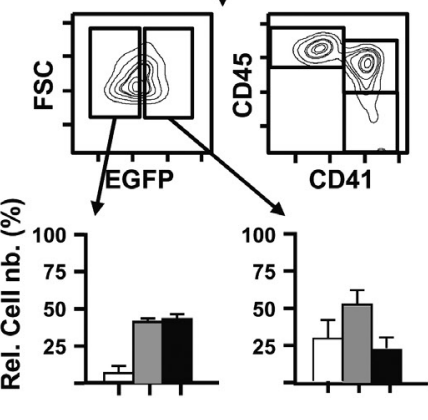
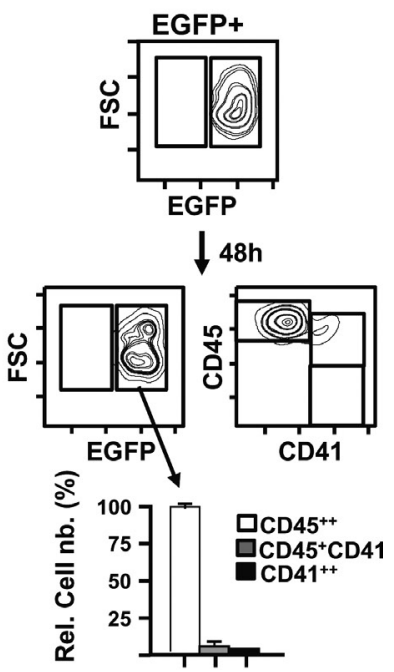

Figure 6. FL CD11 $\mathrm{b}^{+} \mathrm{CD} 115^{+}$cells have a low megakaryocyte-lineage potential at E11.5. (A) E11.5 fetal liver (FL) cell suspensions were stained with anti-Ter119 PerCP-Cy5.5, anti-CD11b-APC, anti-CD45-PE-Cy7, anti-CD41-PE and anti-CD42C-FITC antibodies. A representative contour plot (upper left) of Ter119 cells (electronically excluded) displaying CD11b expression on CD45 $5^{++}$cells is shown. The box inside (R5) shows the CD $45^{+} C D 11 b^{+}$cell population that is analyzed for the expression of CD41 in the bottom left contour plot, identifying cells expressing or not CD41 (R6 and R7 boxes inside the plot). The purified populations of R5/CD45 ${ }^{+} \mathrm{CD} 11 \mathrm{~b}^{+}$, $\mathrm{R} 6 / \mathrm{CD} 45^{+} \mathrm{CD} 11 \mathrm{~b}+\mathrm{CD} 41$ and $\mathrm{R} 7 / \mathrm{CD} 45^{+} \mathrm{CD} 11 \mathrm{~b}^{+} \mathrm{CD} 41^{+}$cells were cultured in short-term liquid cultures (STLC) for $48 \mathrm{~h}$, recovered and stained as in Figure $5 \mathrm{~B}$. Representative contour plots (upper right) of the cells recovered for the STLC performed with R5/CD $45^{+} \mathrm{CD} 11 \mathrm{~b}^{+}$purified cells are shown. The boxes in the plots indicate the cell subsets analyzed in the bottom graph, which displays the frequency of the cells grown in STLC from R5, R6 and R7 cells. The data are the means \pm standard error of mean (SEM) $(n=3)$. (B) Cell suspensions were prepared from bone marrow (BM) from 2-month old C57BL/6 and MaFIA mice, and were stained with anti-CD45-PE-Cy7, anti-CD41-PE, anti-CD9-APC and CD115-BV605. The C57BL/6 preparations also included an anti-CD42c-FITC. Fluorescence-minus-one (FMO) isotype controls for the CD115 and the CD42c antibodies were included. Representative contour plots display the CD41/CD42c/CD115 (upper plot and histogram) or the EGFP/CD41 (bottom plot) signals corresponding to CD9 ${ }^{+++}$cells (left plot) from C57BL/6 and MaFIA mice, respectively. The histogram shows the $\mathrm{CD} 115$ signal (filled in gray) displayed by $\mathrm{CD}^{++} \mathrm{CD} 41^{++} \mathrm{CD} 42 \mathrm{C}^{+} \mathrm{BM}$ megakaryocytes from $\mathrm{C} 57 \mathrm{BL} / 6$ mice. The corresponding FM0 isotype control is overlaid (dotted line). Boxes inside the bottom plot indicate the EGFP and EGFP ${ }^{+} \mathrm{CD} 9^{++} \mathrm{CD} 41^{++}$cells that were purified by cell sorting and analyzed by real-time quantitative polymerase chain reaction (RT-qPCR) for the expression of NE-F2 and VWF transcripts as in Figure 4E. The results of the RT-qPCR are displayed in the bottom histograms as means \pm SEM $(n=3)$. The upper right graph displays the frequency of the cells in EGFP and EGFP+ regions (data are the means \pm SEM, $n=4)$. (C) The expression of CD115 in E11.5 FL cell preparations from MaFIA mice embryos stained with anti-CD45-PE-Cy7, anti-CD41-PE and anti-CD115-APC antibodies is shown. The quantification of the CD115+ cells among the R1-R4 cell populations (identified as in Figure 4A, left dot-plot) is shown in the graph as means \pm SEM ( $n=3$ ). A representative contour plot (right) of CD115 expression on EGFP cells on electronically gated R1/CD41 CD $45^{++}$cells is shown. The number inside the plot represents the frequency of $\mathrm{CD} 115^{+}$cells in the box. (D) Representative contour plots of the FL cell preparations $(n=3)$ from MaFIA mice embryos at E11.5. Electronically selected EGFP+ $^{+}$and EGFP cells (indicated by boxes inside the plots) were analyzed for expression of CD45 and CD41 by staining with anti-CD45-PE-Cy7 and anti-CD41-PE antibodies. The boxes inside the CD45/CD41 plots indicate the CD45 ${ }^{++} \mathrm{CD} 41$, CD $45^{+} \mathrm{CD} 41^{+}$and $\mathrm{CD} 45 \mathrm{CD} 41^{++}$cells, and the number inside is the percentage of CD45CD41 ${ }^{++}$cells. (E) The contour plots show the analyses of the purified EGFP- and EGFP ${ }^{+}$cells after sorting (upper contour plots) and after $48 \mathrm{~h}$ in STLC (middle contour plots) stained as in panel (D). The bottom graphs represent the frequency of the cell populations identified in the boxes depicted in the CD45/CD41 plots for the EGFP and $\mathrm{EGFP}^{+}$cells that were growing in the STLC. Data are the means \pm SEM $(n=3)$. All fluorescence scales are logarithmic. Results were compared with the two-tailed Student $t$-test. $* P<0.05, * * P<0.01$. 


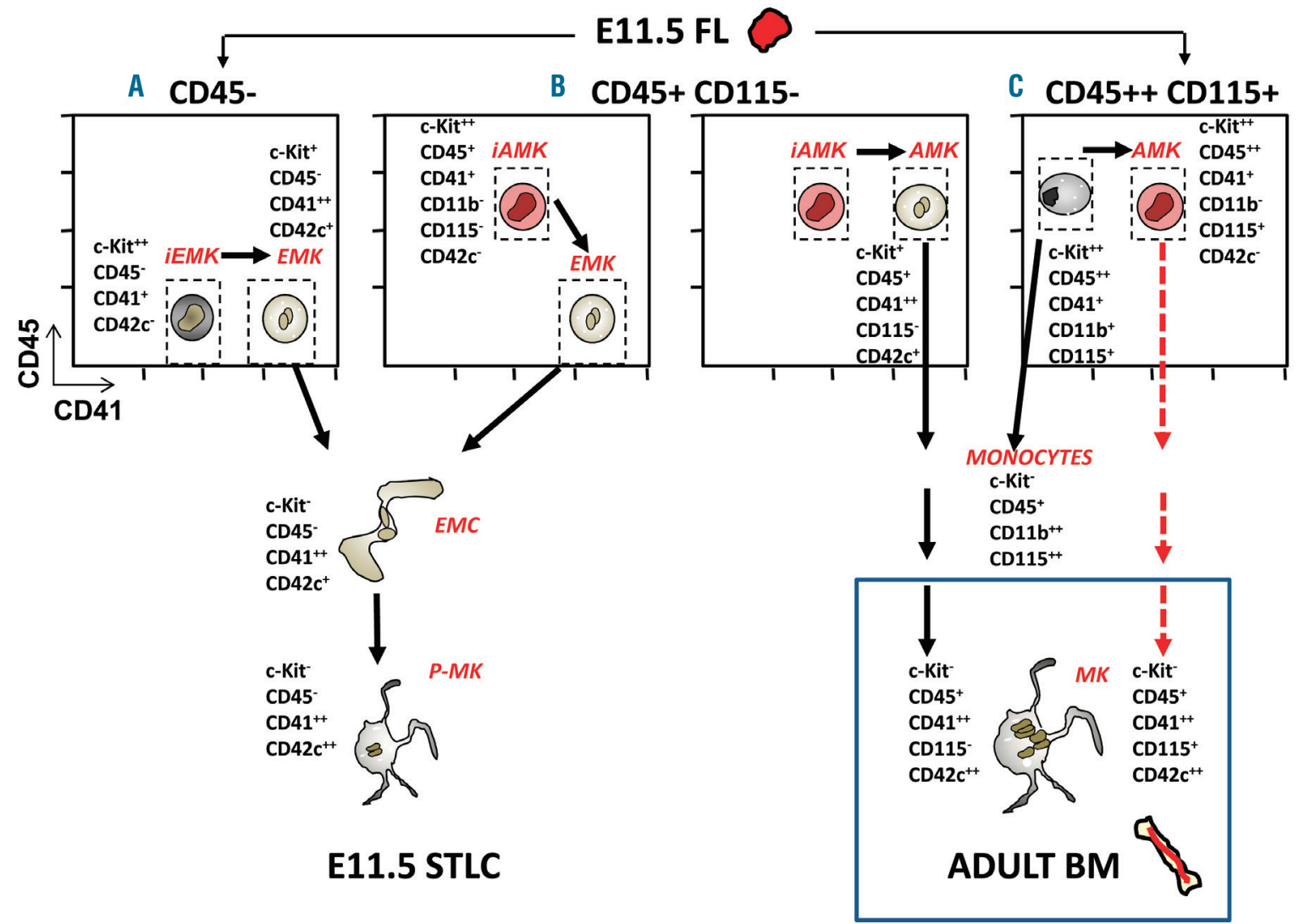

Figure 7. Proposed pathways for megakaryopoiesis in the mouse E11.5 embryo liver and in adult bone marrow. Schematic differentiation pathways proposed from data obtained in the experiments performed with cell populations identified ex vivo in the E11.5 fetal liver (FL) and adult bone marrow (BM), and with the short-term liquid culture (STLC) differentiation analysis of purified subpopulations after staining with CD45, CD41 and CD42C antibodies. (A) Purified CD45 embryonic C$\mathrm{Kit}^{++} \mathrm{CD} 41^{+} \mathrm{CD} 45 \mathrm{CD} 42 \mathrm{C}$ immature embryo-type CD45 megakaryocytes (iEMK) differentiate into c-Kit ${ }^{+} \mathrm{CD} 41^{++} \mathrm{CD} 45 \mathrm{CD}^{\circ} \mathrm{C}^{+}$embryo-type megakaryocytes (EMK) (STLC data in Figure 5B,D), and at $24 \mathrm{~h}$ become elongated mobile cells (EMC) and differentiate into proplatelet-bearing megakaryocytes (P-MK) after $48 \mathrm{~h}$ (bottom left). (B) Purified adult-type $\mathrm{c}-\mathrm{Kit}^{++} \mathrm{CD} 41^{+} \mathrm{CD} 45^{+} \mathrm{CD} 42 \mathrm{c}$ embryonic immature adult-type CD45+ megakaryocytes (iAMK) [highlight for the authors] (that are CD11bCD115; see Figure 6C) differentiate in STLC (data in Figure 5B and 5D) towards CD45- embryonic-type megakaryocytes (EMK) (middle left plot) and to CD45 adult-type megakaryocytes (AMK) (middle-right plot). (C) Cultures from $\mathrm{CD} 41^{+}{ }^{+} \mathrm{CD} 45^{++} \mathrm{CD} 42 \mathrm{c} C \mathrm{CD} 11 \mathrm{~b}^{+} \mathrm{CD} 115^{+}$embryonic progenitors (data in Figure $6 \mathrm{E}$ ) give rise to $\mathrm{CD} 11 \mathrm{~b}^{+}$ myelo/monocytic cells and to a few CD115+ iAMK (right plot). The bottom-right data correspond to the results from ex vivo staining of cell suspensions from adult BM (Figure 6B). The c-Kit data were obtained from staining with anti-c-Kit, anti-CD45 and anti-CD41 as shown in Online Supplementary Figures S5 and S6. Black solid connecting lines indicate results from STLC; red dotted lines are differentiation in adult BM.

changes nor did they develop proplatelets, and most CD $45^{++}$cells were myelo/monocyte-committed CD11b ${ }^{+}$ cells ex vivo (Figure 6A and Online Supplementary Figures S3 and $S 5 D)$. We reasoned that $C D 45^{++}$cells could be a heterogeneous population, containing cells able to differentiate into megakaryocytes. Indeed, low levels of CD41 were expressed in $\mathrm{CD}_{4} 5^{++} \mathrm{CD} 11 \mathrm{~b}^{+}$cells (Figure 6A). We postulated that these $\mathrm{CD} 41^{\text {lo }} \mathrm{CD} 45^{++} \mathrm{CD} 11 \mathrm{~b}^{+}$cells may be able to produce $\mathrm{CD} 41^{++} \mathrm{CD} 45^{+} \mathrm{CD} 42 \mathrm{c}^{+}$megakaryocyte-lineage cells. In fact, more CD41 $1^{++}$cells were obtained in STLC from purified $\mathrm{CD} 41^{\mathrm{lo}} \mathrm{CD} 45^{++} \mathrm{CD} 11 \mathrm{~b}^{+}$cells than in those from $\mathrm{CD} 41 \mathrm{CD}^{-{ }^{+} \mathrm{CD}} 11 \mathrm{~b}^{+}$cells (Figure $6 \mathrm{~A}$ ), and there was a bias towards PF4 expression in cells from $\mathrm{CD} 41^{\text {lo }} \mathrm{CD} 45^{++} \mathrm{CD} 11 \mathrm{~b}^{+}$cultures (Online Supplementary Figure S5D).

To confirm these results we used samples from MaFIA transgenic mice, which allow tracking of cells expressing the macrophage-specific promoter for Csf1r/CD115. ${ }^{29}$ We analyzed BM preparations from adult mice, in which megakaryocytes were identified as Ter119 $\mathrm{CD} 45^{+} \mathrm{CD}^{++} \mathrm{CD} 41^{++} \mathrm{CD} 42 \mathrm{c}^{+}$(Figure 6B). BM megakaryocytes from C57BL/6 mice expressed CD115 (26\% \pm 5.4
$\% ; n=4)$. Accordingly, around 30\% $3.5 \%(n=4)$ of BM megakaryocytes from MaFIA mice were CD45+EGFP ${ }^{++}$ cells expressing NF-E2 and VWF transcripts, although at higher and lower levels, respectively, than those from EGFP- megakaryocytes. When E11.5 FL preparations were analyzed, one fifth of $\mathrm{CD} 41 \mathrm{CD}^{-} 5^{++}$cells actually expressed CD115 brightly at E11.5, and the $\mathrm{CD} 45^{++} \mathrm{CD} 115^{+}$were $\mathrm{EGFP}^{+}$(Figure 6C). However, among these $\mathrm{EGFP}^{+}$cells only around 1\% were $\mathrm{CD} 41^{++} \mathrm{CD} 45^{-} \mathrm{EMK}$ ex vivo (Figure $\left.6 \mathrm{D}\right)$, and when plated in STLC these $\mathrm{EGFP}^{+}$cells mainly produced CD41 CD $45^{++} \mathrm{EGFP}^{+}$cells and low numbers of $\mathrm{CD} 41^{+} \mathrm{CD} 45^{+}$ $\mathrm{EGFP}^{+}$cells (Figure 6E). Surprisingly, after STLC some EGFP cells became $\mathrm{CD} 41^{+} \mathrm{CD} 45^{+/} \mathrm{EGFP}^{+}$and $\mathrm{CD} 41^{++} \mathrm{CD} 45-\mathrm{EGFP}^{+}$cells. This observation indicates that the FL EGFP population contains cells with the potential to become $\mathrm{CD} 115^{+}$in vitro and to generate $\mathrm{CD} 41^{++}$ megakaryocytes, which may be reflecting what happens in vivo in the adult BM. Overall, our findings support the notion of a low potential of embryo $\mathrm{CD} 45^{++}$cells to produce $\mathrm{CD}_{41}{ }^{+}$megakaryocytes in vivo, at difference from the adult BM situation. 


\section{Discussion}

The morphological, functional and molecular changes that take place in the differentiation of megakaryocytes have been assessed here using bulk in vitro cultures of megakaryocyte-committed progenitors from the E11.5 FL. One striking finding was that embryonic $\mathrm{CD} 41^{++} \mathrm{CD} 42 \mathrm{C}^{+} \mathrm{CD} 61^{++} \mathrm{CD}^{++}$megakaryocytes are negative, until E13.5, for the leukocyte common CD45 antigen, a large transmembrane glycoprotein expressed on the surface of all hematopoietic cells and their precursors, except mature erythrocytes and platelets. ${ }^{33,35,36}$ CD 45 accounts for up to $10 \%$ of lymphocyte cell surface proteins and is involved in the dephosphorylation of the regulatory tyrosine of Src family kinases, negatively modulating cell signaling. ${ }^{33,35,36}$ The CD45 protein sets the threshold for signal transduction, and CD45 deficiency produces developmental defects and extended phosphorylation of the JAK/STAT cascade. ${ }^{37}$ The absence of CD45 or diminished levels of this protein have been associated with a hyperadhesive phenotype and impairment of progenitor mobilization from the $\mathrm{BM}^{3 ., 39}$ It could be that the low expression of CD45 may favor the observed accumulation of megakaryocytes in FL at E11.5, together with interactions through integrin receptors that are expressed highly by megakaryocytes.

We used CD41 expression to trace megakaryocytes, since CD41 is expressed strongly by cells of the megakaryocyte lineage, including platelets, in the adult mouse. ${ }^{40} \mathrm{CD} 41$ was defined as a marker for the early stages of primitive and definitive hematopoiesis in the mouse embryo, ${ }^{13}$ and as a marker of HSC in mice and zebrafish, ${ }^{41,42}$ tracing the divergence of definitive hematopoiesis from endothelial cells in mouse c-Kit ${ }^{+}$progenitors. ${ }^{40,43} \mathrm{CD} 41^{++} \mathrm{CD} 45$ megakaryocytes are found in the YS and embryo (P-Sp/AGM, FL) from E9.5 and in the circulating blood, as also reported by others. ${ }^{23}$ Interestingly, E11.5, PreMegE and MKP also display less CD45 than those from newborn and adult BM, whereas CD45 levels appear to be similar in other lineage progenitors, revealing a linkage of the $\mathrm{CD} 45^{- \text {dim }}$ trait to embryo erythroid/megakaryocyte-lineage cells. Since CD41 $1^{++}$ megakaryocytes remain CD45- until E13.5 in the FL, it is tempting to speculate that CD45 EMK may correspond to the primitive wave of megakaryopoiesis generating $\mathrm{CD} 41^{+} \mathrm{CD} 42 \mathrm{c}^{+}$Runx1- diploid platelet-forming cells described in the YS at E10.5. ${ }^{23}$ The progression of primitive HSC to definitive HSC is dependent on RUNX1. ${ }^{20}$ At E11.5 RUNX1-deficient mice have primitive erythrocytes but lack hematopoietic cells in FL and identifiable platelets in blood. ${ }^{44}$ They also lack definitive HSC and CD $45^{+}$cells, and have very few $\mathrm{CD} 41^{++} \mathrm{CD} 45^{\circ}$ cells. ${ }^{20}$ It would thus be conceivable that CD $45^{-}$Runx $1^{+}$megakaryocytes present in the FL at E11.5 belong to the definitive wave of megakaryopoiesis. However, RUNX1 is essential for megakaryocyte maturation in the adult $\mathrm{BM} .^{45}$ Therefore, the fact that EMK in the E11.5 FL are Runx1+, and that many of them are tetraploid cells with larger size than those in the contemporaneous YS, may indicate that the local environment in the FL provides conditions allowing maturation of primitive wave CD45 megakaryocytes. It has been described that megakaryocytes require MPL in order to reach $>8 \mathrm{~N}$ maturation stages after E14.5. ${ }^{24}$ At E11.5, after 2 days in culture, the cell subpopulations isolated from FL produced mostly megakaryocytes with $8 \mathrm{~N}$ ploidy, which may represent the in vitro differentiation of MPL-independent megakaryocytes. Also, at E11.5 FL $\mathrm{R} 4 / \mathrm{CD} 41^{++} \mathrm{CD} 45^{-}$megakaryocytes express the transcription factors NF-E2 and Fli1, in agreement with the findings on a megakaryocyte transcription factor core for YS diploid platelet-forming cells at E10.5 and for FL megakaryocytes at E13.5. ${ }^{24}$

In the FL, CD41 and CD45 expression define several cell subsets at E11.5. CD41 ${ }^{++} \mathrm{CD} 45$ cells are already megakaryocyte-committed $\mathrm{CD} 42 \mathrm{c}^{+} \mathrm{MPL}{ }^{+} \mathrm{CD}{ }^{+} \mathrm{CD}^{++} 1^{++} \mathrm{AChE}^{+}$cells that develop rapidly in culture to P-MK, whereas CD41 $\mathrm{CD}^{+5^{++}}$cells are mostly $\mathrm{CD} 11 \mathrm{~b}^{+}$myelo/monocyte-committed cells. On the other hand, $\mathrm{CD} 41^{+} \mathrm{CD} 45^{+}$and $\mathrm{CD} 41^{+} \mathrm{CD} 45^{\circ}$ cells have a more immature phenotype than the aforementioned populations. The phenotypic data and the gene expression profile ex vivo, as well as in vitro studies of these purified populations, prompt us to propose two major pathways of megakaryocyte differentiation operating in the E11.5 FL (Figure 7): (i) from CD $41^{+} \mathrm{CD} 45$ iEMK, CD41 is upregulated and CD42c is expressed, producing EMK $\left(\mathrm{CD} 41^{++} \mathrm{CD} 45 \cdot \mathrm{CD} 42 \mathrm{c}^{+}\right)$that develop proplatelets with no evidence of CD45 expression (P-MK); (ii) from $\mathrm{CD} 41^{+} \mathrm{CD} 45^{+}$iAMK (that are CD115) (Figure $6 \mathrm{C}$ ), cells enter a $\mathrm{CD} 41^{+} \mathrm{CD} 45^{+} \mathrm{CD} 42 \mathrm{c}^{+}$stage from which $\mathrm{CD} 41^{++} \mathrm{CD} 45 \mathrm{CD} 42 \mathrm{c}^{+}$EMK arise. Therefore, CD45 diminishes when the levels of CD41 of these increase and they acquire CD42c to become EMK. The first pathway is common before E13.5 but becomes rare after E15.5, and it is currently unknown whether it is even retained at low levels in the BM, while the reverse applies to the CD45 derived pathway, although in this case CD45 is retained in $\mathrm{BM} C D 41^{++} \mathrm{CD} 42 \mathrm{c}^{+}$megakaryocytes. Moreover, our data reveal the involvement of Csf1r-expressing cells in adult $\mathrm{BM} \mathrm{CD} 45^{+}$megakaryopoiesis, which may represent a third pathway of megakaryopoiesis (Figure $7 \mathrm{C}$ ), minor or absent in the embryo, and opens the issue of the generation of $\mathrm{CD}_{4} 1^{++}$megakaryocytes from $\mathrm{CD} 45^{++} \mathrm{CD} 115$ expressing cells in the adult. Csf1r/CD115 is considered a mature monocytic differentiation receptor, ${ }^{46}$ but besides the high expression of Csf1 $\mathrm{r}$ in monocytes, macrophages, osteoclasts and myeloid dendritic cells, it is also expressed at low levels on HSC, CMP and CLP, as well as among several non-hematopoietic embryonic cells. ${ }^{47}$ More work is needed to clarify the differential contribution of these $\mathrm{CD} 45^{++} \mathrm{CD} 11 \mathrm{~b}^{+} \mathrm{CD} 115^{+}$cells to adult and embryo megakaryopoiesis and its relevance.

Embryo-fetal-derived megakaryocytes engraft poorly into adult mice and produce low number of platelets. ${ }^{48,49} \mathrm{It}$ is presently unknown whether the different subsets of megakaryocyte progenitors identified in the embryo may give rise to functional or immature platelets in vivo, but they may represent new tools to uncover the mechanisms underlying the maturation of the membrane demarcation system assembly machinery that yields platelets, similarly as the recently described mechanisms by which BM megakaryocytes sense extracellular matrix rigidity to release platelets. ${ }^{50}$ In summary, we present a number of findings proving that embryo megakaryocytes are hematopoietic CD45 nucleated cells that are produced from $\mathrm{CD} 45$ and $\mathrm{CD} 45^{+}$progenitor cells, findings that may be extended to human cord blood samples in order to probe the existence of a human CD45 megakaryocyte counterpart. These issues have relevant implications for understanding aberrant megakaryopoiesis processes and megakaryocyte-derived tumors, and also represent a tool 
that may provide clues to improve megakaryocyte reconstitution by using cord blood-derived progenitors for transplantation and for designing better conditions to increase platelet production to treat thrombocytopenic pathologies.

\section{Funding}

This work was supported by grants from the Ministerio de Ciencia e Innovación (MICINN SAF2009-12596) and from the Ministerio de Economía y Competitividad (MINECO SAF2012-33916 and SAF2015-70880-R MINECO/FEDER). NS was the recipient of a fellowship from the Centro de Biologia
Molecular Severo Ochoa (CBMSO) and IC received a fellowship from the MICINN. The CBMSO receives institutional funding from Fundación Ramón Areces. The CNIC is supported by the MEIC and the Pro CNIC Foundation, and is a Severo Ochoa Center of Excellence (MEIC award SEV-2015-0505).

\section{Acknowledgments}

The authors would like to thank Miriam Pérez-Crespo and Eduardo Martorell for help with animal care, Fernando Gonzalez for support with the confocal microscopy and Mark Shefton, medical writer from BioMedRed Company, for editing the manuscript.

\section{References}

1. Luc S, Anderson K, Kharazi S, et al. Downregulation of $\mathrm{Mpl}$ marks the transition to lymphoid-primed multipotent progenitors with gradual loss of granulocyte-monocyte potential. Blood. 2008;111(7):3424-3434.

2. Boyer SW, Schroeder AV, Smith-Berdan S, Forsberg EC. All hematopoietic cells develop from hematopoietic stem cells through Flk2/Flt3-positive progenitor cells. Cell stem cell. 2011;9(1):64-73.

3. Akashi K, Traver D, Miyamoto T, Weissman IL. A clonogenic common myeloid progenitor that gives rise to all myeloid lineages. Nature. 2000;404(6774):193-197.

4. Kondo M, Weissman IL, Akashi K. Identification of clonogenic common lymphoid progenitors in mouse bone marrow. Cell. 1997:91(5):661-672.

5. Sanjuan-Pla A, Macaulay IC, Jensen CT, et al. Platelet-biased stem cells reside at the apex of the haematopoietic stem-cell hierarchy. Nature. 2013;502(7470):232-236

6. Nishikii H, Kanazawa Y, Umemoto T, et al. Unipotent megakaryopoietic pathway bridging hematopoietic stem cells and mature megakaryocytes. Stem Cells. 2015;33(7):2196-2207.

7. Paul F, Arkin Y, Giladi A, et al Transcriptional heterogeneity and lineage commitment in myeloid progenitors. Cell. 2015;163(7):1663-1677.

8. Perie L, Duffy KR, Kok L, de Boer RJ, Schumacher TN. The branching point in erythro-myeloid differentiation. Cell. 2015; 163(7):1655-1662.

9. Nakorn TN, Miyamoto T, Weissman IL. Characterization of mouse clonogenic megakaryocyte progenitors. Proc Natl Acad Sci U S A. 2003;100(1):205-210.

10. Pronk CJ, Rossi DJ, Mansson R, et al. Elucidation of the phenotypic, functional, and molecular topography of a myeloerythroid progenitor cell hierarchy. Cell Stem Cell. 2007;1(4):428-442.

11. Martinez-Agosto JA, Mikkola HK, Hartenstein V, Banerjee U. The hematopoietic stem cell and its niche: a comparative view. Genes Dev. 2007;21(23):3044-3060

12. Mikkola HK, Orkin SH. The journey of developing hematopoietic stem cells. Development. 2006;133(19):3733-3744.

13. Ferkowicz MI, Starr M, Xie X, et al. CD41 expression defines the onset of primitive and definitive hematopoiesis in the murine embryo. Development. 2003;130(18):43934403.

14. Palis J, Robertson S, Kennedy M, Wall C,
Keller G. Development of erythroid and myeloid progenitors in the yolk sac and embryo proper of the mouse. Development. 1999:126(22):5073-5084.

15. Godin IE, Garcia-Porrero JA, Coutinho A, Dieterlen-Lievre F, Marcos MA. Para-aortic splanchnopleura from early mouse embryos contains B1a cell progenitors. Nature. 1993:364(6432):67-70.

16. Marcos MA, Godin I, Cumano A, et al. Developmental events from hemopoietic stem cells to B-cell populations and Ig repertoires. Immunol Rev. 1994;137:155-171.

17. Medvinsky AL, Samoylina NL, Muller AM, Dzierzak EA. An early pre-liver intraembryonic source of CFU-S in the developing mouse. Nature. 1993;364(6432):64-67.

18. Medvinsky A, Dzierzak E. Definitive hematopoiesis is autonomously initiated by the AGM region. Cell. 1996;86(6):897-906.

19. North T, Gu TL, Stacy T, et al. Cbfa2 is required for the formation of intra-aortic hematopoietic clusters. Development. 1999;126(11):2563-2575.

20. Liakhovitskaia A, Rybtsov S, Smith T, et al. Runx1 is required for progression of CD 41+ embryonic precursors into HSCs but not prior to this. Development. 2014;141(17): 3319-3323

21. Tober J, Koniski A, McGrath KE, et al. The megakaryocyte lineage originates from hemangioblast precursors and is an integral component both of primitive and of definitive hematopoiesis. Blood. 2007;109(4): 1433-1441

22. Xu MJ, Matsuoka S, Yang FC, et al. Evidence for the presence of murine primitive megakaryocytopoiesis in the early yolk sac. Blood. 2001;97(7):2016-2022

23. Potts KS, Sargeant TJ, Markham JF, et al. A lineage of diploid platelet-forming cells precedes polyploid megakaryocyte formation in the mouse embryo. Blood. 2014;124 (17):2725-2729

24. Potts KS, Sargeant TJ, Dawson CA, et al. Mouse prenatal platelet-forming lineages share a core transcriptional program but divergent dependence on MPL. Blood. 2015;126(6):807-816.

25. Pastos KM, Slayton WB, Rimsza LM, Young L, Sola-Visner MC. Differential effects of recombinant thrombopoietin and bone marrow stromal-conditioned media on neonatal versus adult megakaryocytes. Blood. 2006;108(10):3360-3362.

26. Slayton WB, Wainman DA, Li XM, et al. Developmental differences in megakaryocyte maturation are determined by the microenvironment. Stem Cells. 2005;23(9): 1400-1408.
27. Matsumura G, Sasaki K. The ultrastructure of megakaryopoietic cells of the yolk sac and liver in mouse embryo. Anat Rec. 1988;222(2):164-169.

28. Serrano N, Cortegano I, Ruiz C, et al. Megakaryocytes promote hepatoepithelial liver cell development in E11.5 mouse embryos by cell-to-cell contact and by vascular endothelial growth factor A signaling. Hepatology. 2012;56(5):1934-1945.

29. Burnett SH, Kershen EJ, Zhang J, et al. Conditional macrophage ablation in transgenic mice expressing a Fas-based suicide gene. J Leukoc Biol. 2004;75(4):612-623.

30. Marcos MA, Morales-Alcelay S, Godin IE, Dieterlen-Lievre F, Copin SG, Gaspar ML Antigenic phenotype and gene expression pattern of lymphohemopoietic progenitors during early mouse ontogeny. J Immunol. 1997;158(6):2627-2637.

31. Gozalbo-Lopez B, Andrade P, Terrados G, et al. A role for DNA polymerase $\mathrm{mu}$ in the emerging DJH rearrangements of the postgastrulation mouse embryo. Mol Cell Biol. 2009:29(5):1266-1275

32. Eckly A, Heijnen H, Pertuy F, et al. Biogenesis of the demarcation membrane system (DMS) in megakaryocytes. Blood. 2014;123(6):921-930.

33. Charbonneau H, Tonks NK. 1002 protein phosphatases? Annu Rev Cell Biol. 1992; 8:463-493.

34. Matsumura-Takeda K, Sogo S, Isakari Y, et al. CD41+/CD45+ cells without acetylcholinesterase activity are immature and a major megakaryocytic population in murine bone marrow. Stem Cells. 2007;25(4):862870.

35. Thomas ML. The leukocyte common antigen family. Annu Rev Immunol. 1989;7:339-369.

36. Hermiston ML, Xu Z, Weiss A. CD45: a critical regulator of signaling thresholds in immune cells. Annu Rev Immunol. 2003;21:107-137.

37. Irie-Sasaki J, Sasaki T, Matsumoto W, et al. CD45 is a JAK phosphatase and negatively regulates cytokine receptor signalling. Nature. 2001;409(6818):349-354.

38. Shivtiel S, Kollet O, Lapid K, et al. CD45 regulates retention, motility, and numbers of hematopoietic progenitors, and affects osteoclast remodeling of metaphyseal trabecules. J Exp Med. 2008;205(10):2381-2395.

39. Shivtiel S, Lapid K, Kalchenko V, et al. CD45 regulates homing and engraftment of immature normal and leukemic human cells in transplanted immunodeficient mice. Exp Hematol. 2011;39(12):1161-1170.e1

40. Zhang J, Varas F, Stadtfeld M, Heck S, Faust $\mathrm{N}$, Graf T. CD41-YFP mice allow in vivo 
labeling of megakaryocytic cells and reveal a subset of platelets hyperreactive to thrombin stimulation. Exp Hematol. 2007;35(3): 490-499.

41. Bertrand JY, Kim AD, Teng S, Traver D. CD41+ cmyb+ precursors colonize the zebrafish pronephros by a novel migration route to initiate adult hematopoiesis. Development. 2008;135(10):1853-1862.

42. Mitjavila-Garcia MT, Cailleret M, Godin I, et al. Expression of CD41 on hematopoietic progenitors derived from embryonic hematopoietic cells. Development. 2002;129 (8):2003-2013.

43. Boisset JC, van Cappellen W, Andrieu-Soler C, Galjart N, Dzierzak E, Robin C. In vivo imaging of haematopoietic cells emerging from the mouse aortic endothelium. Nature. 2010:464(7285):116-120.

44. Okuda T, van Deursen J, Hiebert SW, Grosveld G, Downing JR. AML1, the target of multiple chromosomal translocations in human leukemia, is essential for normal fetal liver hematopoiesis. Cell. 1996;84 (2):321-330.

45. Ichikawa M, Asai T, Saito T, et al. AML-1 is required for megakaryocytic maturation and lymphocytic differentiation, but not for maintenance of hematopoietic stem cells in adult hematopoiesis. Nat Med. 2004;10(3): 299-304.

46. Lieu YK, Reddy EP. Impaired adult myeloid progenitor CMP and GMP cell function in conditional c-myb-knockout mice. Cell
Cycle. 2012;11(18):3504-3512

47. Stanley ER, Chitu V. CSF-1 receptor signaling in myeloid cells. Cold Spring Harb Perspect Biol. 2014;6(6):a021857.

48. Fuentes R, Wang Y, Hirsch J, et al. Infusion of mature megakaryocytes into mice yields functional platelets. J Clin Invest. 2010;120(11):3917-3922.

49. Sim X, Poncz M, Gadue P, French DL Understanding platelet generation from megakaryocytes: implications for in vitroderived platelets. Blood. 2016;127(10):1227 1233.

50. Abbonante V, Di Buduo CA, Gruppi C, et al. A new path to platelet production through matrix sensing. Haematologica. 2017;102(7): 1150-1160. 